\title{
Microbial Technologies Employed for Biodegradation of Neonicotinoids in the Agroecosystem
}

\author{
Sajjad Ahmad, Dongming Cui, Guohua Zhong and Jie Liu* \\ Key Laboratory of Integrated Pest Management of Crop in South China, Ministry of Agriculture and Rural Affairs, Key \\ Laboratory of Natural Pesticide and Chemical Biology, Ministry of Education, South China Agricultural University, \\ Guangzhou, China
}

\section{OPEN ACCESS}

Edited by: Hendrik Schäfer,

University of Warwick, United Kingdom

Reviewed by: Hai-Ming Zhao, Jinan University, China

Guilan Duan,

Research Center

for Eco-Environmental Sciences, Chinese Academy of Sciences (CAS),

China

*Correspondence: Jie Liu

jieliu@scau.edu.cn

Specialty section:

This article was submitted to Microbiotechnology,

a section of the journal

Frontiers in Microbiology

Received: 16 August 2021

Accepted: 25 October 2021

Published: 02 December 2021

Citation:

Ahmad S, Cui D, Zhong G and Liu J (2021) Microbial Technologies

Employed for Biodegradation of Neonicotinoids

in the Agroecosystem.

Front. Microbiol. 12:759439. doi: 10.3389/fmicb.2021.759439
Neonicotinoids are synthetic pesticides widely used for the control of various pests in agriculture throughout the world. They mainly attack the nicotinic acetylcholine receptors, generate nervous stimulation, receptor clot, paralysis and finally cause death. They are low volatile, highly soluble and have a long half-life in soil and water. Due to their extensive use, the environmental residues have immensely increased in the last two decades and caused many hazardous effects on non-target organisms, including humans. Hence, for the protection of the environment and diversity of living organism's the degradation of neonicotinoids has received widespread attention. Compared to the other methods, biological methods are considered cost-effective, eco-friendly and most efficient. In particular, the use of microbial species makes the degradation of xenobiotics more accessible fast and active due to their smaller size. Since this degradation also converts xenobiotics into less toxic substances, the various metabolic pathways for the microbial degradation of neonicotinoids have been systematically discussed. Additionally, different enzymes, genes, plasmids and proteins are also investigated here. At last, this review highlights the implementation of innovative tools, databases, multiomics strategies and immobilization techniques of microbial cells to detect and degrade neonicotinoids in the environment.

Keywords: neonicotinoids, microbial degradation, metabolites, immobilization, non-target organisms

\section{INTRODUCTION}

Since the global implementation of synthetic insecticides-centered strategies for pest prevention from the 1960s, the satisfaction of increase in crop yield has been compromised by the unexpected pest resistance against mainstream insecticides such as organophosphates (OPs), carbamates, and pyrethroids (Jayaraj et al., 2016). As a promising alternative, neonicotinoid pesticides (Table 1) that mainly target the nicotinic acetylcholine receptor (nAChR) and impact nervous, sympathetic, and parasympathetic systems of insects were first launched in the 1990s (Sparks and Nauen, 2015). Chemical, physical and biological properties of neonicotinoids were collected from Pesticide Properties Database $\left(\mathrm{PPDB}^{1}\right)$. Currently, this group has been developed as the most intensively used insecticide globally, authorized for more than 140 crops in about 120 countries (Table 2; Wood and Goulson, 2017; Zhang et al., 2018a).

\footnotetext{
${ }^{1}$ https://sitem.herts.ac.uk/aeru/ppdb/en/index.htm, accessed: 23 May 2021.
} 
TABLE 1 | Neonicotinoid compounds their chemical structures, physical state, molecular mass, molecular formula, melting point and water solubility.

\begin{tabular}{|c|c|c|c|c|c|c|}
\hline Compound name & Physical state & $\begin{array}{l}\text { Molecular } \\
\text { formula }\end{array}$ & $\begin{array}{l}\text { Molecular mass } \\
\left(\mathbf{g} \cdot \mathrm{mol}^{-1}\right)\end{array}$ & Melting point $\left({ }^{\circ} \mathrm{C}\right)$ & $\begin{array}{l}\text { Water Solubility } \\
\text { (mg/L) }\end{array}$ & Chemical structure \\
\hline Acetamiprid & $\begin{array}{l}\text { White crystals, } \\
\text { white fine } \\
\text { powder, } \\
\text { odorless }\end{array}$ & $\mathrm{C}_{10} \mathrm{H}_{11} \mathrm{CIN}_{4}$ & 222.68 & 98.9 & 2950 & \\
\hline Clothianidin & $\begin{array}{l}\text { Clear colorless } \\
\text { solid powder, } \\
\text { odorless }\end{array}$ & $\mathrm{C}_{6} \mathrm{H}_{8} \mathrm{CIN}_{5} \mathrm{O}_{2} \mathrm{~S}$ & 249.68 & 176.8 & 304 & \\
\hline Cycloxaprid & $\begin{array}{l}\text { Wettable } \\
\text { powder }\end{array}$ & $\mathrm{C}_{14} \mathrm{H}_{15} \mathrm{CIN}_{4} \mathrm{O}_{3}$ & 322.75 & - & - & \\
\hline Imidacloprid & $\begin{array}{l}\text { Clear crystals } \\
\text { or beige } \\
\text { powder }\end{array}$ & $\mathrm{C}_{9} \mathrm{H}_{10} \mathrm{ClN}_{5} \mathrm{O}_{2}$ & 255.67 & 144 & 610 & \\
\hline Nitenpyram & $\begin{array}{l}\text { Pale yellow } \\
\text { crystals }\end{array}$ & $\mathrm{C}_{11} \mathrm{H}_{15} \mathrm{CIN}_{4} \mathrm{O}_{2}$ & 270.72 & 82 & 590000 & \\
\hline Sulfoxaflor & White solid & $\mathrm{C}_{10} \mathrm{H}_{10} \mathrm{~F}_{3} \mathrm{~N}_{3} \mathrm{OS}$ & 277.27 & 112.9 & 568 & \\
\hline
\end{tabular}

Source: Casida, 2011; Sheets et al., 2016; Pang et al., 2020; Pietrzak et al., 2020; and Data from Hazardous Substance Data Bank (HSDB), available at: https: //sitem.herts.ac.uk/aeru/ppdb/en/index.htm (Accessed: 23 May 2021).

TABLE 2 | Typical neonicotinoid insecticides and their basic characteristics.

\begin{tabular}{|c|c|c|c|c|c|}
\hline Category & Name & $\begin{array}{l}\text { Year of } \\
\text { registration }\end{array}$ & Target arthropods & Crops & References \\
\hline $\begin{array}{l}\text { First generation } \\
\text { (chloropyridinyl } \\
\text { compounds) }\end{array}$ & $\begin{array}{l}\text { Imidacloprid } \\
\text { Nitenpyram } \\
\text { Acetamiprid } \\
\text { Thiacloprid }\end{array}$ & $\begin{array}{l}1992 \\
1995 \\
2002 \\
2003\end{array}$ & $\begin{array}{l}\text { Whiteflies, termites, beetles, fleas, ants, bugs, } \\
\text { centipedes, cockroaches, crickets, earwigs, flies, } \\
\text { millipedes, mosquitoes, moths, scorpions, silverfish, } \\
\text { spider mites, spiders, ticks, wasps and aphids }\end{array}$ & $\begin{array}{l}\text { Ornamental plants, cotton, rice, } \\
\text { cereals, peanuts, vegetables, } \\
\text { pome fruits, pecans, }\end{array}$ & $\begin{array}{l}\text { Shao et al., 2008; } \\
\text { Fairbrother et al., 2014; } \\
\text { Hussain et al., 2016; } \\
\text { Thompson et al., } 2020\end{array}$ \\
\hline $\begin{array}{l}\text { Second generation } \\
\text { (chlorothiazolyl } \\
\text { compounds) }\end{array}$ & $\begin{array}{l}\text { Thiamethoxam } \\
\text { Clothianidin }\end{array}$ & $\begin{array}{l}2001 \\
2003\end{array}$ & $\begin{array}{l}\text { Aphids, thrips, beetles, centipedes, millipedes, } \\
\text { sawflies, leaf miners, stem borers, termites. flies, } \\
\text { moths and true bugs }\end{array}$ & $\begin{array}{l}\text { Vegetables, ornamental plants, } \\
\text { citrus, cotton, rice, corn, } \\
\text { tobacco, canola, grapes }\end{array}$ & $\begin{array}{l}\text { Fairbrother et al., 2014; } \\
\text { Zhao et al., } 2020\end{array}$ \\
\hline $\begin{array}{l}\text { Third generation } \\
\text { (tetrahydrofuryl } \\
\text { compound) }\end{array}$ & $\begin{array}{l}\text { Cycloxaprid } \\
\text { Dinotefuran } \\
\text { Sulfoxaflor }\end{array}$ & $\begin{array}{l}2008 \\
2012 \\
2013\end{array}$ & $\begin{array}{l}\text { Aphids, whiteflies, thrips, leafhopper, planthoppers, } \\
\text { leaf miner, sawfly, mole cricket, white grubs, bugs, } \\
\text { psyllids, beetles, mealybugs, sawfly larvae and } \\
\text { cockroaches. }\end{array}$ & $\begin{array}{l}\text { Cotton, rice, mustard, turf, lawn } \\
\text { \& garden, vegetable crops, } \\
\text { alfalfa, cacao, citrus, corn, } \\
\text { cucurbits, grains, pineapples }\end{array}$ & $\begin{array}{l}\text { Hussain et al., 2016; } \\
\text { Liao et al., } 2019\end{array}$ \\
\hline
\end{tabular}


In general, neonicotinoid insecticides are mainly used for sucking, boring, and root-feeding pests like Lepidoptera, Coleoptera, and Hemiptera, respectively (Cimino et al., 2017; Halsch et al., 2020). Since some Hemipteran insects (like aphids) can spread viruses in plants, this group is also recommended against the spread of disease viruses in crops (Simon-Delso et al., 2015). Additionally, neonicotinoids are used for wood protection against the attack of termites (Hano et al., 2019). Due to broad-spectrum and mode of action, they are highly employed as veterinary medicines to prevent different animal pests like fleas, ticks, and worms (Pisa et al., 2015). However, only $5 \%$ of neonicotinoid pesticides can reach specific targets during field application (Acero et al., 2019). Due to the extensive consumption, the residues of neonicotinoids are ubiquitously found in the environment at the levels of parts per billion and million (ppb-ppm) in soil and plants, while it is parts per trillion (ppt) in water (Bonmatin et al., 2015; Morrissey et al., 2015), which become a serious threat to a wide range of non-targeted organisms (Figure 1).

The typical neonicotinoids, such as imidacloprid and clothianidin, produce sub-lethal effects on other living organisms, including genotoxicity, cytotoxicity, immunosuppression, reduced growth, and reproduction disorder in the vertebrates (Gibbons et al., 2015; Han et al., 2018). Recently, Schulz et al. (2021) found that the neonicotinoid exposure and toxicity have increased significantly to the aquatic invertebrates, pollinators, genetically modified crops (corn and soybeans), and terrestrial plants. It has been reported that neonicotinoid residues at high levels may seriously threaten the vertebrates' reproductive and developmental systems (fish, mammals, birds, reptiles, amphibians) and even humans (Berheim et al., 2019). Neonicotinoids are also evaluated to increase the aromatase expression to participate in vitro models related to human breast cancer development and change the function of critical antioxidant enzymes like catalase, superoxide, dismutase, and glutathione peroxidase (Annabi et al., 2015; Caron-Beaudoin et al., 2018). More alarmingly, increasing shreds of evidence showed that the intensive use of neonicotinoids at the flowering and blooming stages might become the major cause for the colony collapse disorder within the predators and pollinators, especially bees (Woodcock et al., 2017). Mitchell et al. (2017) found that due to the imprudent use of neonicotinoids (acetamiprid, clothianidin, imidacloprid thiacloprid, and thiamethoxam), the habitat of pollinators and the quality of honey were severely affected. Around the globe, 198 honey samples were analyzed, among $75 \%$ contained at least one class of neonicotinoid, while $45 \%$ contained two or five and $10 \%$ contained four or five in quantifiable amounts. Moreover, this study indicated that the North American (86\%), Asian (80\%), and European (79\%) regions had the ubiquitous existence of neonicotinoid residues in honey samples.

To alleviate the environmental toxicity of neonicotinoids, effective, low-cost, and sustainable methods are urgently needed to degrade neonicotinoid residues. In general, the reduction of toxic substances from the environment can be achieved by several methods such as physical adsorption and advanced oxidant process (Ye et al., 2019). Among all the techniques, biodegradation by microorganisms is considered to be more efficient, reliable, eco-friendly, and cost-effective (Li et al., 2020). For decades, a large variety of microbial species have been discovered for the degradation of pesticide residues. More importantly, many isolates reveal attractive properties such as the complete mineralization of pesticides and their toxic metabolites, endowing the approach of microbial degradation with high potential for future practical application (Yue et al., 2018).

To achieve the effective degradation of neonicotinoids, the study of enzymes involved in its metabolism imparts foundational insights for understanding the transformation pathway, which ultimately influences the efficacy of the biodegradation strategy. In particular, a cell-free extract containing abundant intracellular enzymes has been widely employed as one of the most versatile and efficient techniques. Furthermore, recent molecular advances have empowered omics approaches and databases to provide new insights that contribute to the discipline of biodegradation by allowing concurrent analysis of millions of microbes and cover the path of pesticide biodegradation. Hence, this review aims to summarize the strength and molecular basis of microbial degradation for neonicotinoid pollution. Also, we focus on the recent development of microbial active element-centered techniques using whole cells, enzymes, genes, plasmids, and modern biological molecular tools, which establish a myriad of promising strategies to promote the potential for environmental monitoring and biodegradation neonicotinoids.

\section{POTENTIAL MICROORGANISMS FOR NEONICOTINOID DEGRADATION AND THEIR METABOLIC PATHWAYS}

Functional microbes, mainly bacteria and fungi isolated from contaminated soil, water, and sediment, are considered one of the most versatile candidates for the efficient and effective biodegradation of persistent pesticides in the agricultural ecosystem (Kumar et al., 2019). The extensive use of neonicotinoids in various crops has raised a significant concern due to their toxicity and persistence in the ecological system and human health. Recently, Menon et al. (2021) proposed a study about the perseverance of different types of neonicotinoids in the water soil systems of the paddy fields in the Cauvery delta region, South India. This study revealed that the neonicotinoids are less persistent in the water soil systems, and they are readily exposed to photolysis and undergo efficient microbial degradation. Moreover, hydropedological characteristics of highly saturated delta soil enable their leaching into groundwater by vertical migration and infiltration.

Various studies have confirmed that a wide range of microbes are capable of degrading neonicotinoids in not only liquid cultures but also in a contaminated environment (Table 3). Recently, García-Galán et al. (2020) degraded various types of neonicotinoids (acetamiprid, clothianidin, imidacloprid, thiacloprid, and thiamethoxam) through microalgae species (Ulothrix sp., Oocystis sp., and Synechocystis sp.) in wastewater using semi-closed, tubular horizontal photobioreactor (PBR). 


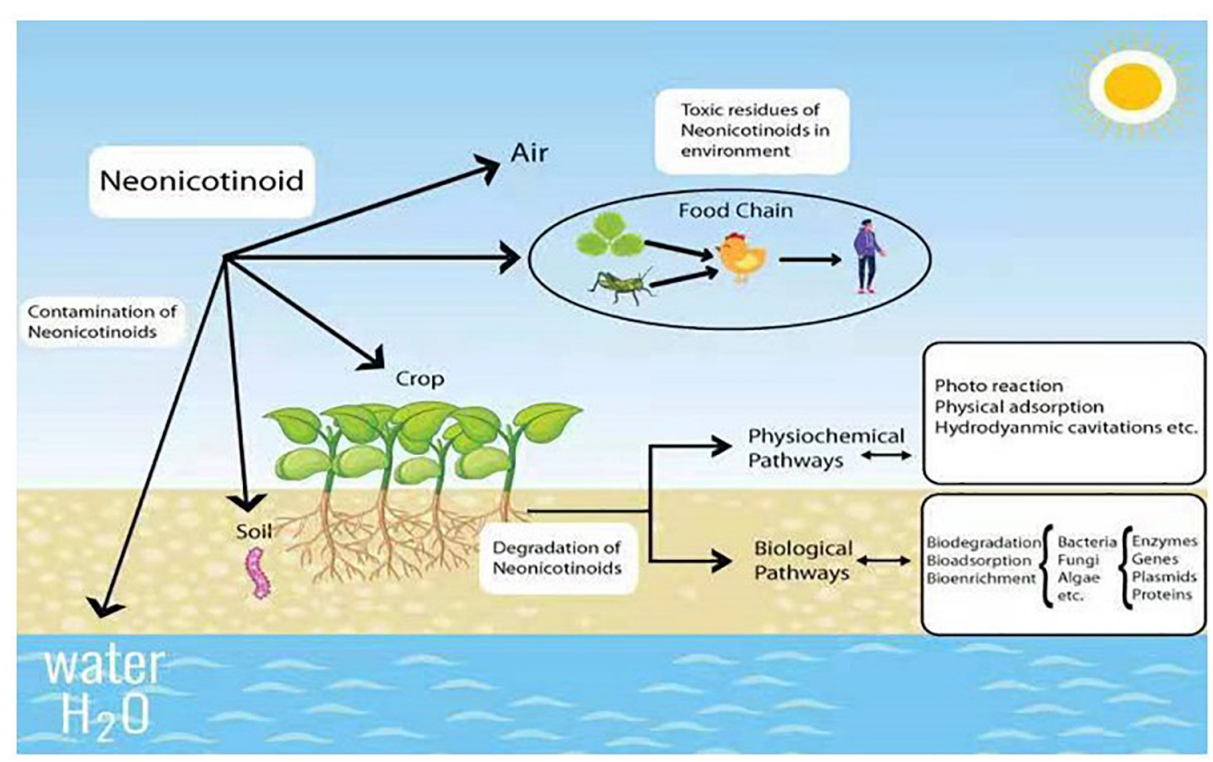

FIGURE 1 | Neonicotinoid contamination and their degradation by various methods.

This study highlighted new data on the ability of microalgaebased treatment systems to degrade not only different types of neonicotinoids but also non-targeted pesticide transformation products or their intermediates into the original compounds using PBR. Furthermore, this study could provide a practical and feasible explanation even in higher concentrations in the effluents under real environmental conditions.

Biodegradation of neonicotinoids and other pesticides in the groundwater occurred in the absence or deficiency of oxygen conditions with the correlation of anaerobic microorganisms (Pietrzak et al., 2020). The biodegradation of clothianidin under anaerobic and aerobic conditions was studied by Mulligan et al. (2016). Various parameters were also investigated, such as the effect of nutrients, concentration of pesticide, and temperature. Results showed that the clothianidin degradation rate was higher in anaerobic conditions than aerobic conditions at different temperature ranges. Monsalvo et al. (2014) designed an experiment for the anaerobic biodegradation of imidacloprid in an expanded granular sludge bioreactor (EGSB) and revealed that imidacloprid dramatically decreased in EGSB. After 30 days, for the degradation of imidacloprid with the concentration of $20 \mathrm{mg} / \mathrm{L}$, the EGSB gained a stable chemical oxygen demand of $0.9 \mathrm{~g} \mathrm{CH}_{4}-\mathrm{COD} / \mathrm{g} \mathrm{COD}$ and methane production of around $85 \%$, respectively. In another study, Gupta et al. (2008) found anaerobic conditions for microbial species to degrade thiamethoxam, resulting in $\mathrm{DT}_{50}$ values of 46-75 days that are more effective, fast, and efficient. For the resourceful removal of neonicotinoids in agriculture wastewater, Rodríguez-Castillo et al. (2019) isolated eight bacterial and one yeast strain. The biological process was sealed up in batch stirred tank bioreactors and degraded mixtures of neonicotinoids (imidacloprid + thiamethoxam and imidacloprid + thiamethoxam + acetamiprid) $95.8 \%$ and $94.4 \%$ of total neonicotinoids, respectively.
Microbes and duckweed species (Lemna turionifera and Ceratophyllum demersum) for the biotransformation of imidacloprid and thiacloprid were collected from pond water. The results of this study explained that the removal of tested neonicotinoids required the presence of duckweed and its associated microbial community, which suggested that this mechanism was synergistic. In the presence of duckweed and microbes, imidacloprid and thiacloprid were efficiently degraded in the hydroponic medium at the rates $0.63 \pm 0.07$ and $0.62 \pm 0.05$ per day, respectively. Furthermore, their degradation (imidacloprid and thiacloprid) converted into multiple intermediates such as desnitro-imidacloprid, imidacloprid urea, thiacloprid amide, and 6-chloronicotinic acid. This novel study provides new insights to remove hazardous substances and excellent contribution to the environmental fate of neonicotinoids (Muerdter and LeFevre, 2019). Another study removed neonicotinoids (acetamiprid, imidacloprid, thiamethoxam) and other organic and inorganic emerging pollutants by a monoculture of Chlorella vulgaris and mixed microalgal-bacterial culture for the conventional wastewater treatment. Both C. vulgaris and mixed microalgal-bacterial batch cultures could remove neonicotinoids and other hazardous pollutants. The monoculture of microalgal degrades (imidacloprid and acetamiprid) rapidly and proposed various transformation pathways, suggesting that increasing algae concentration in full-scale algae-based treatment systems can improve their removal rate and efficiency. The results of this study also suggested that environmentally relevant spiked concentrations $(1-20 \mu \mathrm{g} / \mathrm{L})$ did not inhibit the growth of micro-algal and C. vulgaris cultures (Prosenc et al., 2021). A yeast was identified instead of bacterial and fungal strains for the degradation of different classes of neonicotinoids such as acetamiprid, imidacloprid, imidaclothiz and thiacloprid as 
TABLE 3 | The ability of isolated microorganisms in degrading various neonicotinoids.

\begin{tabular}{|c|c|c|c|c|}
\hline Target neonicotinoid & Microorganisms & Source & Degradation (\%) & References \\
\hline & Streptomyces canus & Soil & 90.32 & Guo et al., 2019 \\
\hline & Fusarium sp. & Contaminated soil & 99.6 & Shi et al., 2018 \\
\hline & Staphylococcus aureus strain 502 & Wetland wastewater & 61.68 & Kanjilal et al., 2016 \\
\hline & Pseudoxanthomonas sp. AAP-7 & Polluted soil & 100 & Wang et al., 2013b \\
\hline & Rhodococcus sp. BCH-2 & Contaminated soil & 84.65 & Phugare and Jadhav, 2015 \\
\hline & Stenotrophomonas sp. THZ-XP & Sludge & 100 & Tang et al., 2012 \\
\hline & Pseudomonas aeruginosa BCRC 11864 & Commercial & 76.55 & Toolabi et al., 2017 \\
\hline \multirow[t]{2}{*}{ Clothianidin } & $\begin{array}{l}\text { Ochrobactrum anthropi, Acinetobacter johnsonii, } \\
\text { Pseudomonas sp. and Stenotrophomonas maltophilia }\end{array}$ & Vegetable green house & 79.3 & Wang et al., 2018 \\
\hline & Pseudomonas stutzeri & Soil & 62 & Parte and Kharat, 2019 \\
\hline \multirow[t]{9}{*}{ Imidacloprid } & Bacillus aerophilus & Sandy loam soil & $81.20-99.14$ & Akoijam and Singh, 2015 \\
\hline & $\begin{array}{l}\text { Methylobacterium radiotolerans and Microbacterium } \\
\text { arthrosphaerae }\end{array}$ & Corn field & $88.4-98.7$ & Erguven and Yildirim, 2019 \\
\hline & Pseudomonas, Enterobacter, Aspergillus and Rhodotorula & Strawberry field & 80 & Li et al., 2020 \\
\hline & Mycobacterium sp. & Wheat and clover field & 99.7 & Kandil et al., 2015 \\
\hline & Hymenobacter latericoloratus CGMCC & Water & $52.4-68.2$ & Guo et al., 2020 \\
\hline & Aspergillus terreus YESM3 & Wastewater drains & 96.23 & Mohammed and Badawy, 2017 \\
\hline & Ochrobactrum BCL-1 & Tea rhizosphere soil & 78 & Hu et al., 2013 \\
\hline & Pseudomonas sp. RPT 52 & Agriculture field & 46.5 & Gupta et al., 2016 \\
\hline & Rhizobium sp. & $\begin{array}{l}\text { Vegetable farming } \\
\text { areas }\end{array}$ & 45.48 & $\begin{array}{l}\text { Sabourmoghaddam et al., } \\
2015\end{array}$ \\
\hline \multirow{2}{*}{ Nitenpyram } & Rhodococcus ruber CGMCC 17550 & Sewage & 98.37 & Dai et al., 2021 \\
\hline & Aspergillus sp. & $\begin{array}{l}\text { Commercial formulation } \\
\text { biotechnology }\end{array}$ & 92.9 & Chen et al., 2019 \\
\hline Sulfoxaflor & Aminobacter sp. CGMCC 1.17253 & Agriculture soil & 59.1 & Yang W. L. et al., 2020 \\
\hline \multirow[t]{11}{*}{ Thiamethoxam } & $\begin{array}{l}\text { Acinetobacter sp., Enterobacter sp. and } \\
\text { Bacillus sp. }\end{array}$ & Soil & $82.06-94.72$ & Hegde et al., 2017 \\
\hline & Enterobacter sp. TMX13 & $\begin{array}{l}\text { Roots of mulberry } \\
\text { (Morus alba L.) }\end{array}$ & 85.2 & Wang W. et al., 2020 \\
\hline & $\begin{array}{l}\text { Bacillus aeromonas IMBL 4.1, } \\
\text { Pseudomonas putida IMBL 5.2, Acinetobacter sp. TW and } \\
\text { Sphingomonas sp. TY }\end{array}$ & Agriculture soil & $38.23-45.28$ & Rana et al., 2015 \\
\hline & Ensifer adhaerens TMX-23 & Agriculture soil & 81 & Zhou et al., 2013 \\
\hline & Enterobacter cloacae TMX-6 & Rice field & 99 & Zhan et al., 2021 \\
\hline & Pseudomonas fluorescens & Isle cultures & 67 & Zamule et al., 2021 \\
\hline & Pseudomonas putida & Isle cultures & 65 & Zamule et al., 2021 \\
\hline & Escherichia coli & Isle cultures & 60 & Zamule et al., 2021 \\
\hline & Pseudomonas sp. $1 \mathrm{G}$ & Soil & 70 & Pandey et al., 2009 \\
\hline & Phanerochaete chrysosporium & Commercial & 98 & Chen et al., 2021 \\
\hline & $\begin{array}{l}\text { (Mix microbial culture of genera) Achromobacter, Agromyces, } \\
\text { Ensifer, Mesorhizobium, Microbacterium and } \\
\text { Pseudoxanthomonas }\end{array}$ & Soil & 96 & Zhou G. C. et al., 2014 \\
\hline
\end{tabular}


TABLE 3 | (Continued)

\begin{tabular}{lllll}
\hline Target neonicotinoid & Microorganisms & Source & Degradation (\%) & References \\
\hline Thiacloprid & Ensifer meliloti CGMCC7333 & Rhizosphere soils & 86.8 & Ge et al., 2014 \\
& Stenotrophomonas maltophilia & China general & 100 & Zhao et al., 2009 \\
& CGMCC1.178 & microbiological (CC) & & Zhang et al., 2012 \\
& Variovorax boronicumulans J1 & Agricultural soils & $62.5-100$ & Zhao et al., 2019b \\
& Microvirga flocculans CGMCC 1.16731 & Contaminated soil & 92.4 & Mori et al., 2021 \\
& Phanerochaete chrysosporium & Rotten wood & 74 & .
\end{tabular}

Rhodotorula mucilaginosa strain IM-2. Results showed that yeast strain efficiently degrade acetamiprid and thiacloprid in sucrose mineral salt medium with half-lives of 3.7 and 14.8 days, respectively. At the same time, no degradation was observed in the case of imidacloprid and imidaclothiz (Dai et al., 2010).

Guo et al. (2020) evaluated oligotrophic bacterial strain Hymenobacter latericoloratus CGMCC 16346 to degrade imidacloprid by co-metabolism hydroxylation. The bacterial cells degraded $64.4 \%$ of $100 \mathrm{mg} / \mathrm{L}$ imidacloprid in surface water. After the incubation of 6 days in the existence of maltose as co-substrate, bacterial enriched culture degraded $40.8 \%$ of imidacloprid in 10 days. The bacterium removed imidacloprid in surface water without co-substrate supplementation and retained imidacloprid-degrading activity after 30 days. Recently, in another study, Encarnação et al. (2021) isolated a microalgae Nannochloropsis sp. from wastewater and investigated it for the bioremediation of imidacloprid with the initial concentration of $9.59 \mu \mathrm{g} / \mathrm{mL}$. Results demonstrated that within $20 \mathrm{~h}$, microalgae degraded $50 \%$ of imidacloprid in synthetic wastewater. Chiral insecticide paichongding is a kind of neonicotinoid promising to replace imidacloprid. Its prominent features include being less toxic to mammals and broad-spectrum mode of action against sucking and biting insect pests widely used in China (Lou et al., 2015). Due to the dramatic effects on the environment, soil microbial community and soil enzyme activity are severely affected by the parent compound and its by-products (Cai et al., 2016; Bian et al., 2018). Wang J. et al. (2016) studied its remediation in an aqueous environment using two bacterial species (Sphingobacterium sp. G1-13 and G1-14), which degrade $35 \%$ in 5 days. Furthermore, in this study, metabolites were also detected and two possible degradation pathways are proposed, which provide new insights into the biodegradation of novel types of neonicotinoids.

To degrade imidacloprid residues using microbial species and to investigate the environmental parameters such as chemical oxygen demand (COD) and biochemical oxygen demand $\left(\mathrm{BOD}_{5}\right)$, a study was carried out by Erguven and Yildirim (2019). Two bacterial species (Methylobacterium radiotolerans and Microbacterium arthrosphaerae) were isolated from the corn field in the Thrace region of Turkey, and both were cultured on plate count agar at $28^{\circ} \mathrm{C}$. After growth of 7 days, $10^{7} \mathrm{CFU} / \mathrm{ml}$ suspensions of each bacterium were used to prepare $100 \mathrm{ml}$ sterile flasks containing $99 \mathrm{ml}$ sabouraud dextrose broth. Further, the mass of flasks was homogenized and designed three different concentrations, $20 \mathrm{ml}, 40 \mathrm{ml}$, and $80 \mathrm{ml}$, to remove imidacloprid at the concentration of
$700 \mathrm{ppm}$. For the biodegradation experiment, three flasks were treated with sterile corn farming soil, mixed bacterial culture, and imidacloprid. In comparison, the blank bottle was treated with imidacloprid and sterile soil. All the flasks were diluted using a $250 \mathrm{ml}$ distilled water. After 18 days, the water filtered sample result showed that mixed microbial culture was able to degrade $98.7 \%, 96.4 \%$, and $51.6 \%$ of imidacloprid, respectively. In the case of $\mathrm{BOD}_{5}$, the same concentrations of mixed microbial culture were able to remove $88.4 \%, 78.6 \%$, and $49.9 \%$ of imidacloprid, respectively. This study concluded that mixed cultures of bacterial species with a concentration of $80 \mathrm{ml}$ and $40 \mathrm{ml}$ provide high degradation rate than the low concentration $(20 \mathrm{ml})$.

To degrade imidacloprid and acetamiprid residues in the environment, a bacterial strain Stenotrophomonas maltophilia CGMCC 1.1788 was used and found that this strain was efficiently involved in the degradation process and detoxified both compounds. The difference in metabolism and detoxification pathways of both pesticides appeared due to structural differences (Chen et al., 2008). In another study same bacterial strain was used by Dai et al. (2006) for the removal of imidacloprid and found that resting cells of this bacterial strain convert imidacloprid into 5-hydroxyl IMI [1-(6-chloro-3-pyridylmethyl)-5-hydroxyl$\mathrm{N}$-nitroimidazolidin-2-ylideneamine] at the maximum conversion rate.

Guo et al. (2019) monitored the degradation of another neonicotinoid, acetamiprid, in the environment via actinomycete Streptomyces canus CGMCC 13662 enriched from the agricultural soil. After $48 \mathrm{~h}$ of incubation, at $200 \mathrm{mg} / \mathrm{L}$, about $70 \%$ degradation of acetamiprid was achieved. The degradation of thiamethoxam was investigated in municipal wastewater, and the microbial action accelerated dissipation by UV light to degrade acetamiprid in the contaminated environment, a bacterial strain ACE-3 was isolated from soil, and results indicated that this strain was able to degrade acetamiprid entirely at the initial concentration of $50 \mathrm{mg} / \mathrm{L}$ within 144 hours in a broad range of environmental conditions such as $\mathrm{pH}(6-8)$ and temperature (20-42 ${ }^{\circ} \mathrm{C}$ ) (Peña et al., 2011; Xu et al., 2020).

For the recovery of clothianidin and acetamiprid, HarryAsobara and Kamei (2019) isolated the bacterial species (Enterobacter sp. TN3W-14 and Pseudomonas sp. TN3W-8) and white-rot fungal specie (Phlebia brevispora) strains TN3F and TMIC33929. The bacterial strains used are promoting the growth of fungal hyphae, and it was shown that growing cocultures of Phlebia and these bacteria appeared to improve the degradation of neonicotinoids based on the decreased recovery 
of the compounds compared to either the axenic fungal culture or the bacterial cultures.

\section{The Microbial Metabolic Pathways for Neonicotinoid Biodegradation}

The excessive use of neonicotinoids has generated long-term toxic residual contamination in the environment (Shahid et al., 2021). More importantly, when various microbes convert the parent compounds, it may lead to intermediates with the same or higher toxicity than the parent compounds (Li, 2021). Consequently, a comprehensive understanding of neonicotinoid biodegradation pathways would help to better utilize these functional microbes for more sustainable remediation.

To degrade clothianidin, the breakdown of C-N bonds between thiazolyl methyl and the guanidine division delivers carbon for the transformation of clothianidin to 2 chloro-5methyl thiazole and methyl nitroguanidine (Parte and Kharat, 2019). The microbial method slowly degraded clothianidin to ((2-chlorothiazol-5-yl) methyl-3-methylguanidine and methyl3 -(thiazol-5-yl) methyl) guanidine via denitrification and dehalogenation (Pang et al., 2020). Mori et al. (2017) studied the clothianidin's degradation and metabolic pathways using pure culture white-rot fungus, Phanerochaete sordida, inoculated from the rotten wood. The degradation metabolite of clothianidin $\mathrm{N}$ (2-chlorothiazol-5-yl-methyl)- $\mathrm{N}^{\prime}$-methyl urea was determined using high-resolution electrospray ionization mass spectrometry technique. Wang et al. (2019c) also reported the degradation of clothianidin. Still, the difference from the above study is the use of bacteria instead of fungi, and results revealed that this compound degraded into further three metabolites, while the one metabolite is identical in the study as mentioned above. The other two metabolites are $\mathrm{N}-(1,3$-thiazole-5-ylmethyl)$\mathrm{N}^{\prime}$-methyl guanidine and 5-amino-methlthiazol. The bacterial strains used in this study (Ochrobactrum anthropi, Acinetobacter johnsonii, Pseudomonas sp., and Stenotrophomonas maltophilia) provided the highest degradation of $79.3 \%$ in the mineral salt medium after the incubation of 15 days. So, this could be due to the use of different microbial species, which give the various metabolites of the same compound (Figure 2).

Imidacloprid is highly persistent in soil with a halflife of more than 100 days (Anhalt et al., 2007). In the case of imidacloprid, oxidation and nitro reduction are the two most essential pathways (Lu et al., 2016). Imidacloprid cleavages into metabolites like urea, 6-chloronicotinic aldehyde, 6-chloro-N-methylnicotinacidamide, and 6-chloronicotinic acid (Sabourmoghaddam et al., 2015; Fusetto et al., 2017). Three main different biological degradation pathways can degrade the imidacloprid: hydroxylation of the imidazolidine ring, reduction of the nitro group, and loss of the nitro group (Figure 3). In another study for the degradation of imidacloprid, a bacterial strain Klebsiella pneumoniae strain $\mathrm{BCH} 1$ was isolated. After optimizing bacterial strain on various environmental conditions, results showed that it was more active at $30{ }^{\circ} \mathrm{C}$ and degraded approximately $78 \%$ of imidacloprid within a week. Moreover, in this study using gas chromatography and mass spectrometry, three metabolites were identified as nitrosoguanidine, imidacloprid guanidine and 6-chloronicotinic acid and toxicity of parent compound and their intermediates were tested using model insect silkworm (Bombyx mori) (Phugare et al., 2013). Ma et al. (2014) proposed the metabolic pathway of imidacloprid by using consortium Pseudoxanthomonas indica CGMCC 6648. In the existence of glucose, the imidacloprid can be degraded to 5-hydroxy imidacloprid and imidacloprid olefin can be degraded in 6 days. In the presence of lactose, imidacloprid can be degraded to 5-hydroxy imidacloprid in $48 \mathrm{~h}$. However, in the presence of pyruvate, it can form olefin imidacloprid in $96 \mathrm{~h}$. P. indica CGMCC 6648 simultaneously degraded the imidacloprid and formed olefin imidacloprid. In another study, Sharma et al. (2014a) also studied the degradation of imidacloprid by Bacillus alkalinitrilicus and proposed possible intermediates such as 6chloronicotinic acid, nitrosimine, and imidacloprid-NTG.

The degradation of acetamiprid and its metabolic pathway was evaluated by Sun et al. (2018) using Ensifer adhaerens CGMCC 6315 , which rapidly degraded $87.8 \%$ of acetamiprid-polluted soil (at the initial concentration of $5 \mathrm{mg} / \mathrm{kg}$ ) within 2 days. During the microbial degradation of acetamiprid, the triple bond between carbon and nitrogen of the compound was oxidized and splintered to produce $\mathrm{N}$-amidoamine derivatives. Due to the uneven breakdown, the product was divided into $\mathrm{N}$-methyl(6-chloro-3-pyridyl) methylamine and (Z)-1-ethylideneurea. The metabolites rapidly produced 6-chloronicotinic acid, which was finally mineralized to $\mathrm{H}_{2} \mathrm{O}$ and $\mathrm{CO}_{2}$. In another study, Shi et al. (2018) demonstrated the metabolic pathway of acetamiprid via Fusarium sp. strain. CS-3 N'-[(6-chloropyridin-3-yl) methyl]$\mathrm{N}$-methylacetamide, 2-chloro-5-hydroxymethylpyridine, and 6chloronicotinic acid were distinguished as the most prevailing intermediates (Figure 4).

The metabolic pathway of thiacloprid was also reported. Zhang et al. (2018b) showed that at least eight bacterial genera were linked to the degradation of thiacloprid into its intermediate thiacloprid amide, which would be related to oxidative cleavage. Recently, Zhao et al. (2019b) demonstrated the transformation of thiacloprid via nitrogen-fixing bacterium Microvirga flocculans CGMCC 1.16731 through the process of hydroxylation and hydration to thiacloprid amide and 4-hydroxy thiacloprid. A cobalt-type nitrile hydratase (nhase) is formed by two subunits, such as $\alpha$-subunit $(\operatorname{tnh} A)$ and a $\beta$-subunit $(\operatorname{tnh} B)$. Both subunits transformed thiacloprid to thiacloprid amide (Figure 5).

Thiamethoxam, 3-(2-chloro-1,3-thiazol-5-yl-methyl)-5methyl-1,3,5-oxadiazinan-ylidene (nitro) amine, is another type of neonicotinoid pesticide that shares the same mechanisms as imidacloprid and has no interactive resistance to imidacloprid, idinidine, or alkenididine (Pang et al., 2020). Pandey et al. (2009) studied the microbial degradation of thiamethoxam and imidacloprid by Pseudomonas sp. 1G, and the results of the study revealed that both pesticides were transformed to nitrosoguanidine $(=\mathrm{N}-\mathrm{NO})$, desnitro $(=\mathrm{NH})$, and urea $(=\mathrm{O})$ metabolites. In another study, a demethylation pathway was adopted to degrade thiamethoxam, forming desmethyl-thiamethoxam (Zhou et al., 2013; Figure 6).

For the biodegradation of nitenpyram and dinotefuran, Wang et al. (2019b) isolated a white-rot fungus, Phanerochaete sordida 


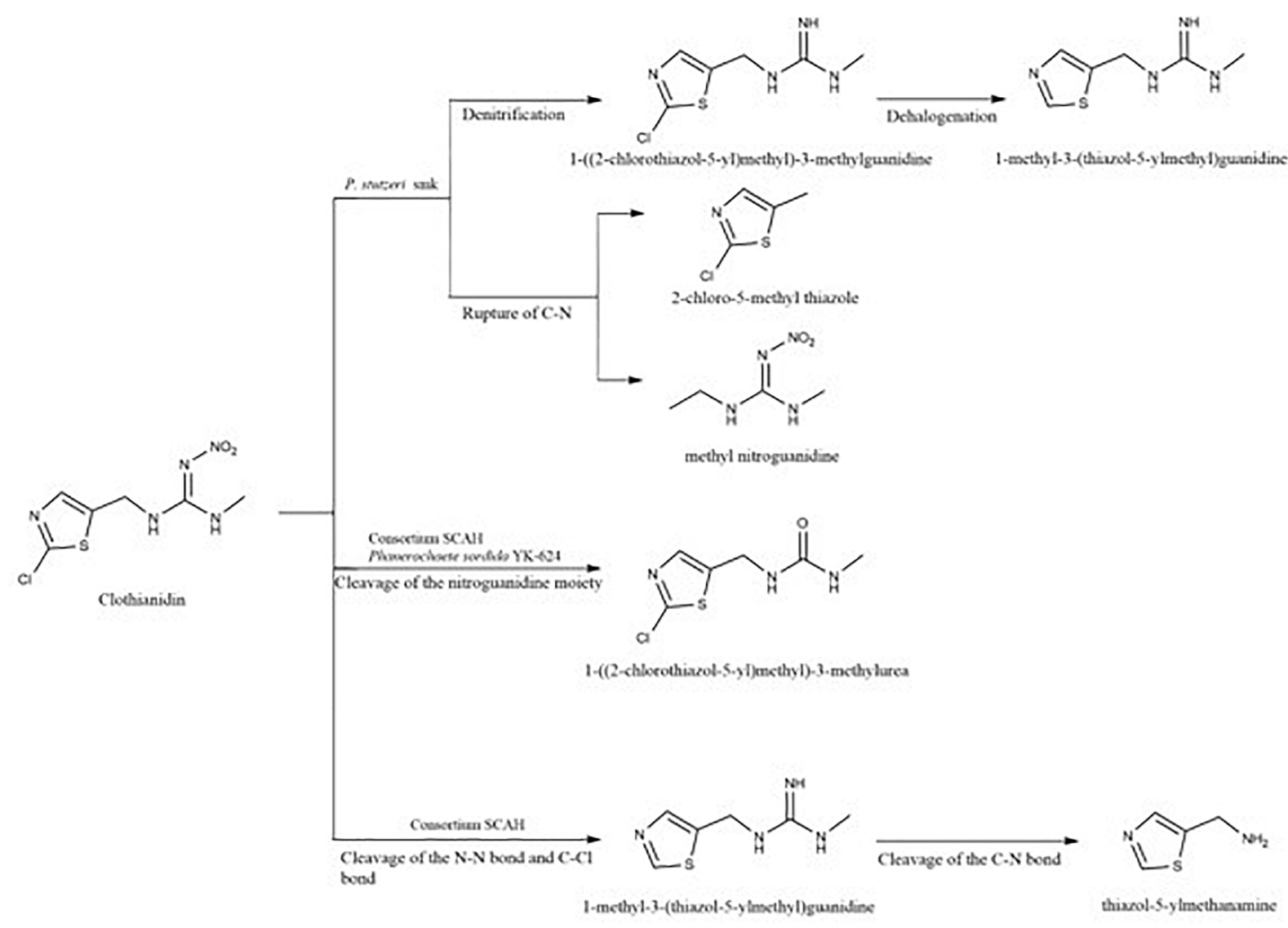

\section{(Darte and Kharat, 2019; Wang et al., 2018; Mori et al., 2017)}

FIGURE 2 | Microbial metabolic pathway of clothianidin and their intermediate products.

YK-624, and proposed their microbial metabolic pathways. Nitenpyram converted into their intermediate (Z)-N-((6chloropyridin-3-yl) methyl)-N-ethyl-N'-hydroxyacetimidamide in two ways, reduction of nitenpyram and by denitrosation or deamination. In the opening ring of the hydroxyl group, by hydroxylation and dehydration pathway, dinotefuran was converted into its metabolites (Figure 7).

\section{MICROBIAL TECHNOLOGIES FOR THE ENHANCED NEONICOTINOID BIODEGRADATION}

There are many different conventional methods and combined technologies used to eliminate toxic pesticide residues from the agroecosystem. These biodegradation methods strive to clean up and transform a massive range of accumulated poisonous compounds in the environment (John et al., 2018). With the improvement of scientific methods by various researchers in biodegradation, gene editing and systematic biological tools are being used to eliminate not only pesticides but also other hazardous wastes (Malla et al., 2018). Using microbial technologies, many effective microbes and their related genes, plasmids, and enzymes useful in biodegradation processes with precise information are identified. The use of microbial technologies fixes the degradation of microbial species and their co-related parts, which are used to deal with pesticide polluted agroecosystem. In recent years, molecular, omics, and database approaches together with immobilization techniques are playing a vital role in the analysis of microbial communities in the contaminated site. These novel techniques provide incredible insights into key biodegradative pathways and the ability of microbes to accept environmental stress conditions. These approaches facilitate the explanation of microbial species at the taxonomic level and provide new insights to access the pool of genetic resources for the development of biodegradation in an agroecosystem (Czaplicki and Gunsch, 2016).

\section{Molecular Approaches}

Nowadays, as compared to the common biological pathways, traditional and advanced molecular biological techniques such as clone libraries, probes, reverse sample genome probing, fluorescent in situ hybridization, community profiling or DNA fingerprinting, next-generation sequencing, pyrosequencing 

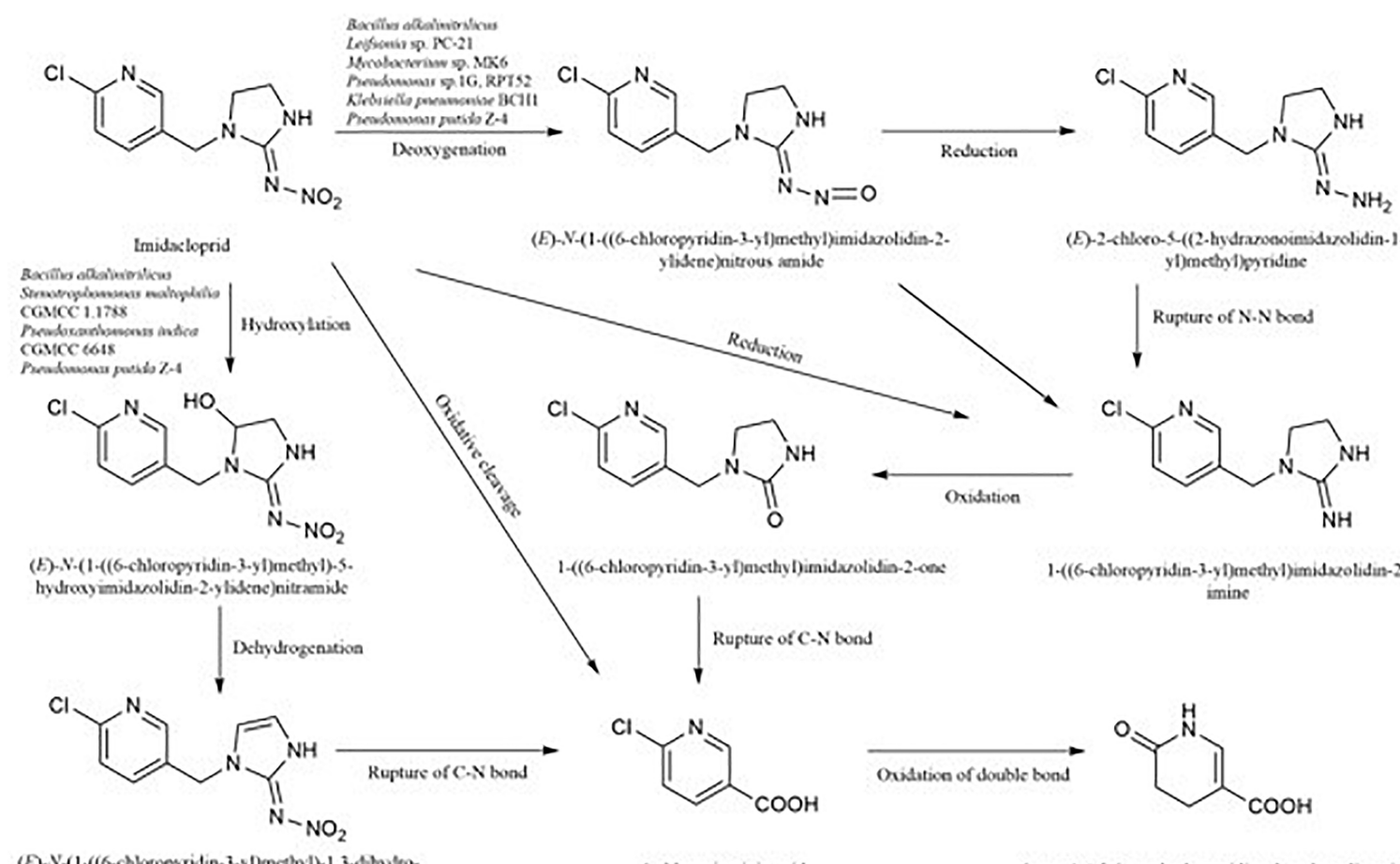

(E)-V-(1-((6-chloregyridin-3-y)methyl)imidacolidia-2-

(E)-2-chloro-4 (2-tydranooimsiderolidin-1.

yiskene)nitrous amide y1)methy 1) pyridine
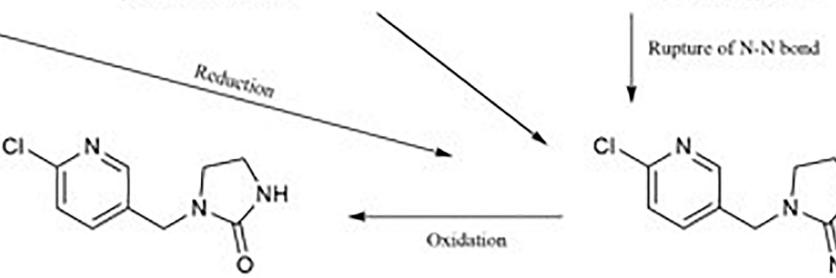

$\checkmark$

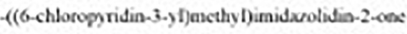

$1 \cdot((6-\operatorname{chl})$ otepyndin-3.y $) \mathrm{me}$
imine

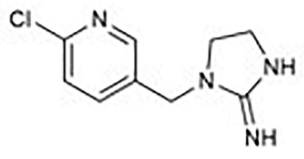

$\mathrm{NH}$

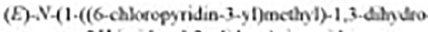

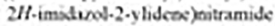

Rupture of C-N bond<smiles>O=C(O)c1ccc(Cl)nc1</smiles>

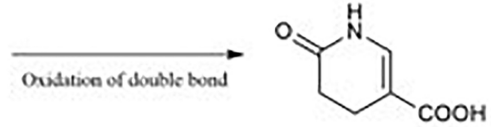

6-chloronicotinic acid

$\mid$ Rupture of C-N tond

2him

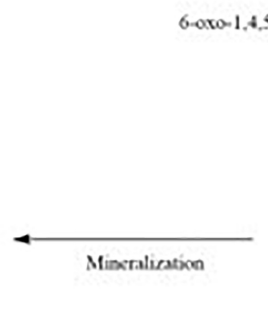

$N$-(1/f-imidunot-2-y) nitramide

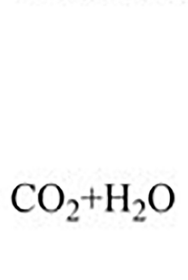

(Gupta et al., 2016; Lu et al., 2016; Kandil et al., 2015; Sharma et al., 2014b; Ma et al., 2014;
Phugare et al., 2013; Pandey et al., 2009; Chen et al., 2008; Anhalt et al., 2007; Dai et al., 2006)

FIGURE 3 | Microbial metabolic pathway of imidacloprid and their intermediate products.

analysis, single-cell genome sequencing, and massively parallel signature sequencing provide a more significant explanation, identification of entire profile, and complete biodiversity of microbial communities (Bailón-Salas et al., 2017). Various techniques associated with enzymes, genes, and DNA of microbes such as genes (plasmids and transposons) are responsible for removing pesticides (Parween et al., 2016). The various molecular strategies which are used for the effective biodegradation of pesticides are restriction fragment length polymorphism (RFLP), dot blot, Southern blot, polymerase change reaction (PCR) amplification, subsequent analysis of bacterial rRNA genes by sequencing, preparing metagenomic libraries, denaturing gradient gel electrophoresis (DGGE), and microarrays (Sinha et al., 2009). Recently, Mori et al. (2021) had studied the degradation of various neonicotinoids by white-rot fungus, Phanerochaete chrysosporium, and identified cytochrome P450 enzyme and two major isoenzymes (CYP5037B3 and
CYP5147A3) involved in the metabolism of three neonicotinoids (acetamiprid, imidacloprid, and thiacloprid). Both isoenzymes catalyzed the breakdown of the chloropyridinyl group and side chain of the three neonicotinoids by the $\mathrm{N}$-dealkylation reaction pathway, resulting in the product in 6-chloro-3pyridinemethanol and respective side chain fragments. In another study for the remediation of imidacloprid, two bacterial species (Ochrobactrum thiophenivorans and Sphingomonas melonis) were isolated from cotton cultivated agricultural soil. Several molecular techniques are used for their identification, such as DNA probes, DNA sequencing, protein synthesis, protein and gene expression analysis, nucleic acid extraction, PCR, and DGGE (Erguven and Demirci, 2021).

In order to further elucidate the molecular mechanism, the enzyme-based removal of xenobiotics is a straightforward, quick, eco-friendly, and socially acceptable approach for biodegradation in the natural environment. So, to fulfill this gap, scientists from 

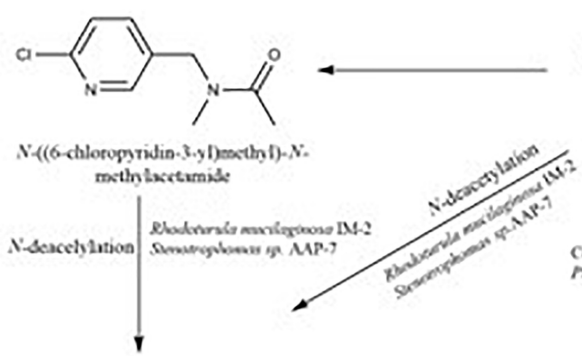<smiles>CC(=NN)N(C)Cc1ccc(Cl)nc1</smiles>
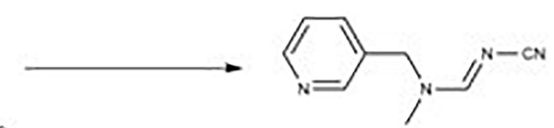<smiles>CNCc1ccc(Cl)nc1</smiles>

1-(6-chloropyridin-3-yl)-. $\mathrm{N}$. methylesethanumine

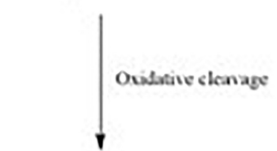<smiles>O=C(O)c1ccc(Cl)nc1</smiles>

Graloroacotinis axid<smiles>O=C1CCC(C(=O)O)=CN1</smiles>

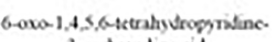
3-ertaxylic axid
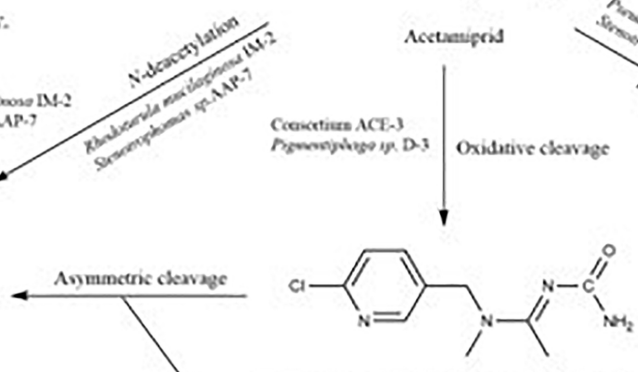
methy taxetimidnide

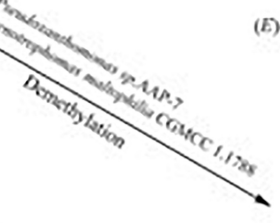

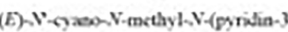
Vecth f) formimidumide cynosctimidumale

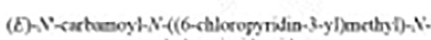<smiles>CN=C(C)NCc1ccc(Cl)nc1</smiles>

(E)-N-4(6-etworop) ritin-3-y Demethy) N:

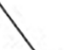

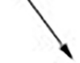

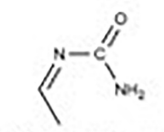

(C) - 1-reblytidencurea

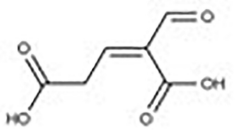

$\underset{\text { Mincraliation }}{\longrightarrow} \mathrm{CO}_{2}+\mathrm{H}_{2} \mathrm{O}$

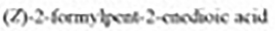

(Xu et al., 2020; Wang et al., 2013a, b; Tang et al., 2012; Dai et al., 2010; Chen et al., 2008)

FIGURE 4 | Microbial metabolic pathway of acetamiprid and their intermediate products.<smiles>ON=C1SCCN1Cc1ccc(Cl)nc1</smiles>

Thisckoprid

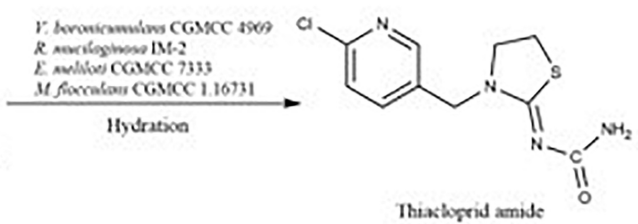

Thi:kbrid amide

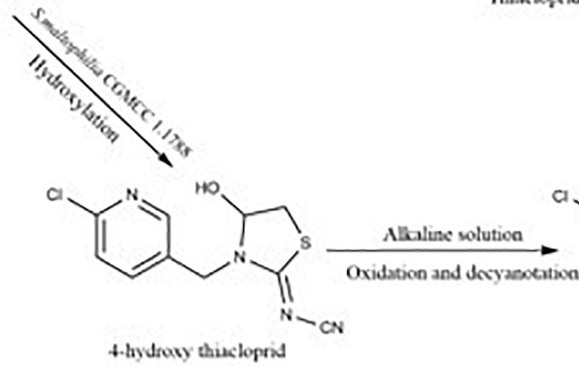

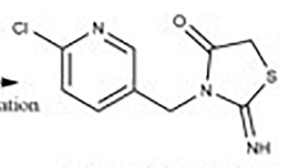

4.kctoos thiaksprid imin:

(Zhao et al., 2019b; Ge et al., 2014; Zhang et al., 2012; Dai et al., 2010; Zhao et al., 2009)

FIGURE 5 | Microbial metabolic pathway of thiacloprid and their intermediate products. 


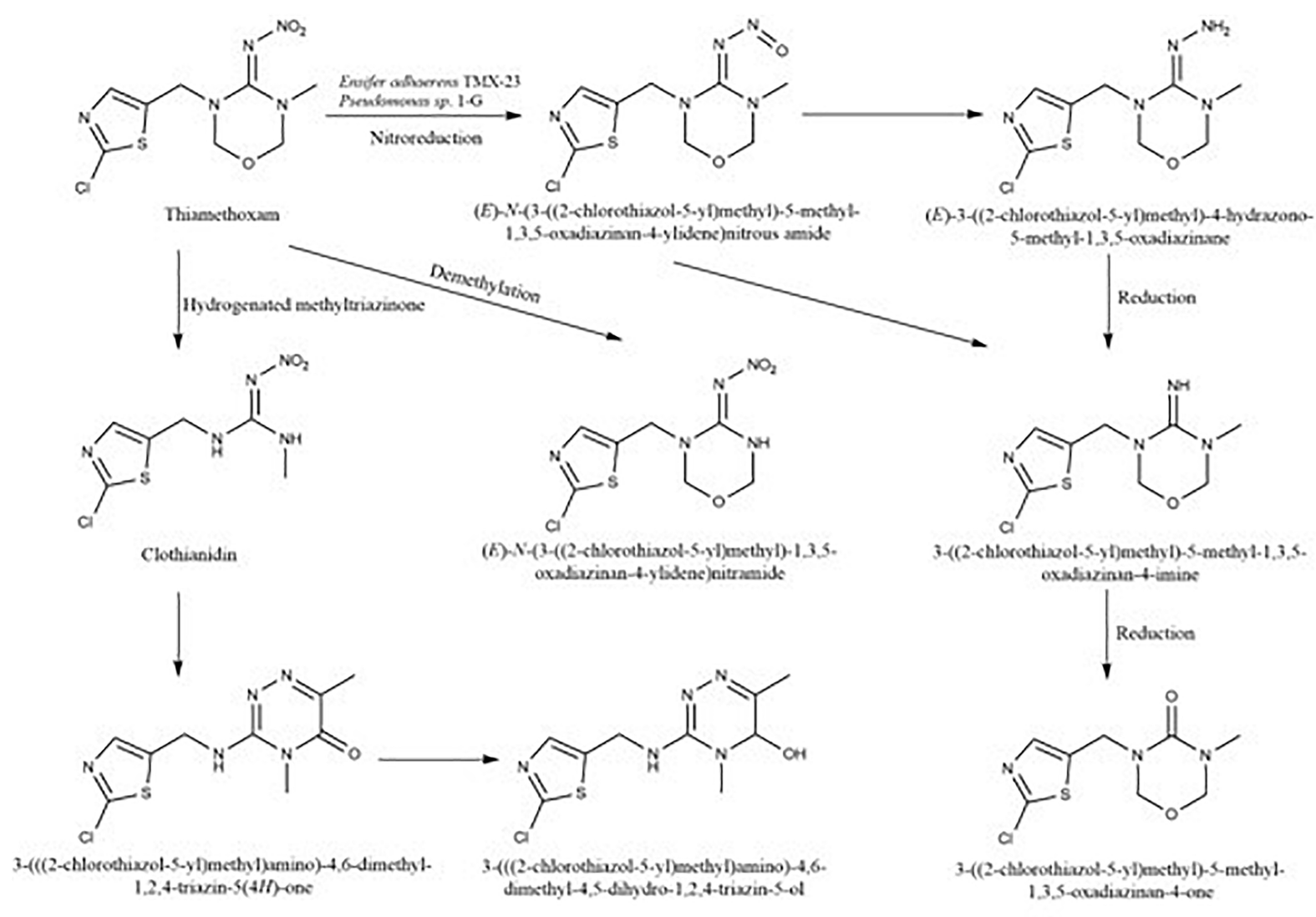

(Zhou et al., 2013; Pandey et al., 2009)

FIGURE 6 | Microbial metabolic pathway of thiamethoxam and their intermediate products.

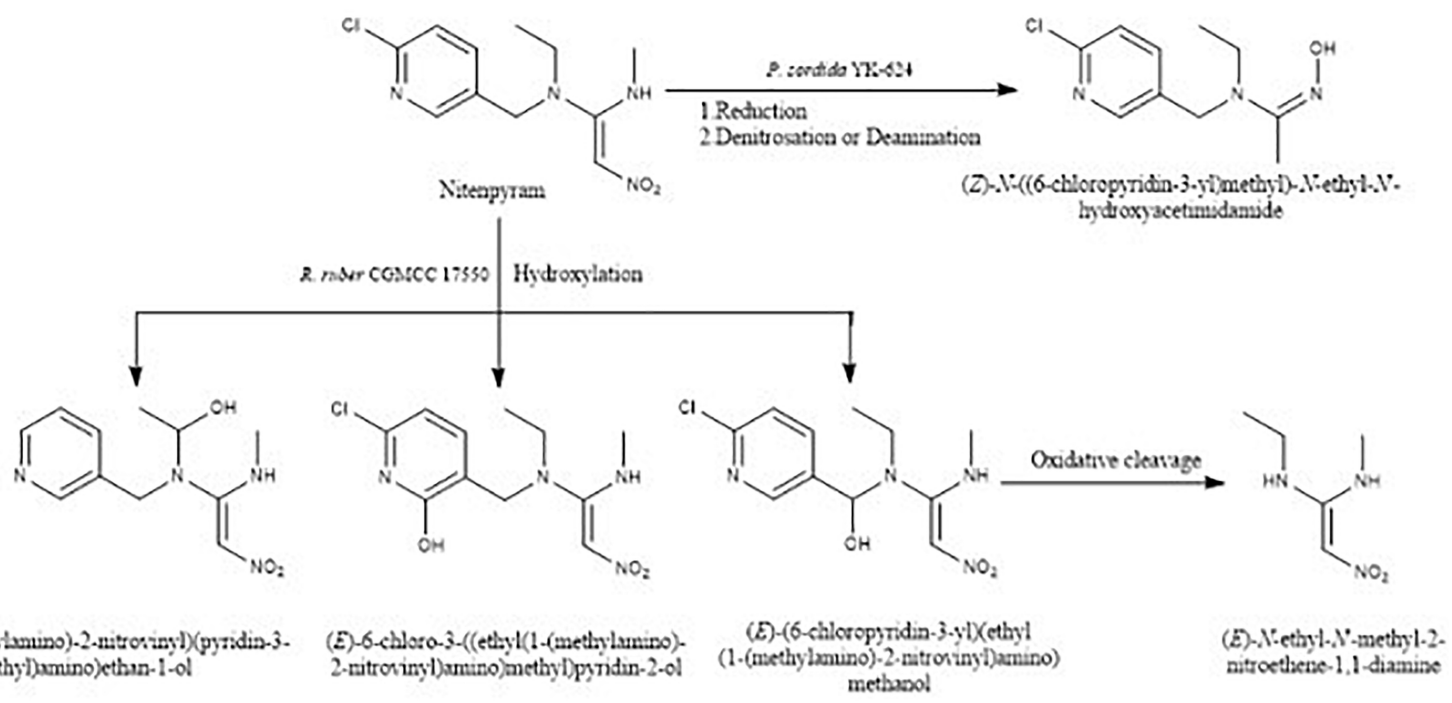

(Dai et al., 2021; Wang et al., 2019b)

FIGURE 7 | Microbial metabolic pathway of nitenpyram and their intermediate products. 

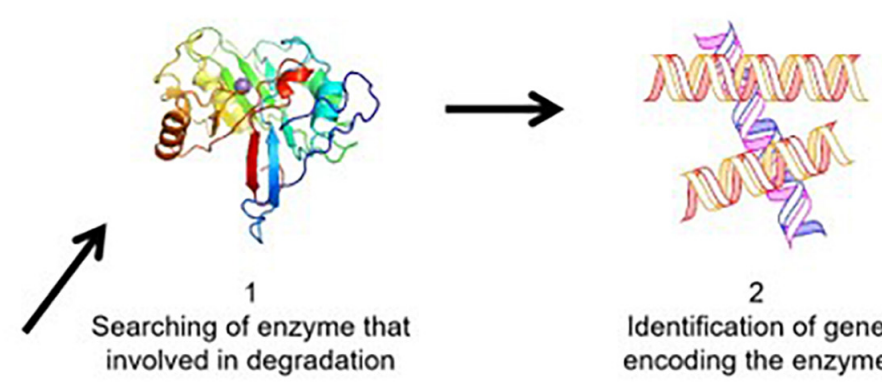

2

Identification of gene encoding the enzyme

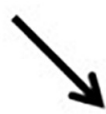

3

Enzyme shelf life and their environmental stability

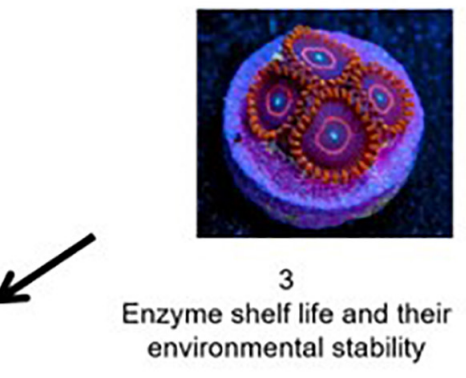

Commerical production of enzyme

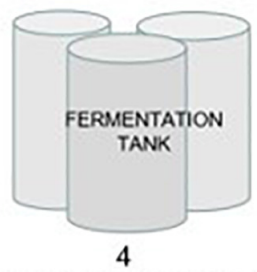

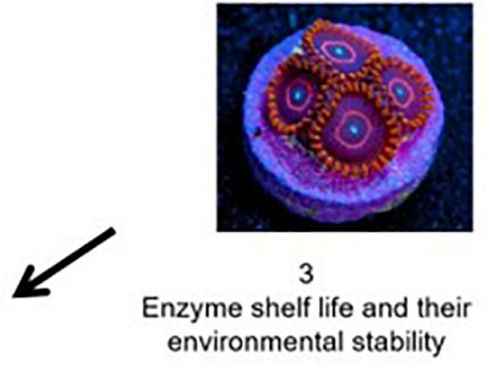

Improvement in enzyme production

FIGURE 8 | Schematic strategy for the purification of novel enzymes involved in biodegradation.

all over the world have been working continuously to provide the most effective solution to increase environmental pollution (Sharma et al., 2018). A schematic diagram for the purification of novel enzymes by different sources has been illustrated in Figure 8. There are many enzymes that were purified by different sources which are involved in the bioremediation of neonicotinoids enlisted in Table 4.

For the bioremediation of acetamiprid in surface water, Sun et al. (2017) had used plant growth-promoting rhizobacterium, Variovorax boronicumulans CGMCC 4969, and their enzymatic mechanism was also investigated. The bacterium removed $34.7 \%$ of $2 \mathrm{mg} / \mathrm{L}$ acetamiprid over $120 \mathrm{~h}$ with a degradation halflife of $182 \mathrm{~h}$, and the major intermediate was the amide product, (E)- $\mathrm{N}^{2}$-carbamoyl- $\mathrm{N}^{1}$-[(6-chloro-3-pridyl) methyl]$\mathrm{N}^{1}$-methylacetamidine (IM-1-2). Gene cloning and overexpression related studies proved that a nitrile hydratase mediated acetamiprid hydration to IM-1-2. Yang H. et al. (2020) studied the enzymatic degradation pathway of acetamiprid using the Pigmentiphaga $s p$., facilitated by nitrile hydratase. Additionally, amidase and its encoding genes such as aceA and $a c e B$ are used for effective degradation. In general, ace $B$ and a novel amidase showed the ability of initially hydrolyzing the C-N bond of acetamiprid to produce 1-(6-chloropyridin3-yl)-N-methylmethanamine (IM 1-4), which achieved almost complete degradation of acetamiprid (Figure 3). In another study, Yang W. L. et al. (2020) studied the degradation of sulfoxaflor insecticide by enzymatic mechanism. A bacterium was isolated and identified as Aminobacter sp. CGMCC 1.17253 that degraded sulfoxaflor, while recombinant Escherichia coli strain protected the Aminobacter sp. CGMCC 1.17253 nitrile hydratase gene and the pure nitrile hydratase cobalt-containing with the subunits of $\alpha, \beta$, attachment proteins, and threedimensional homology of nitrile hydratase were obtained. The substrate specificity test of this study further explained that these enzymes play a significant role in other neonicotinoids such as acetamiprid and thiacloprid into their relative amide's intermediates. By the hydration pathway, the bacterial strains convert sulfoxaflor into their intermediate [N-(methyl(oxido) $\{1-$ [6- (trifluoromethyl)pyridin-3-yl] ethyl\}-k4-sulfanylidene) urea] (Yang et al., 2021).

Cytochrome P450s played a vital role in the metabolism of organic pollutants using rot fungi (Mori et al., 2017). Wang et al. (2019a) demonstrated the enzyme P450 (enriched by Phanerochaete chrysosporium) to degrade neonicotinoid insecticide acetamiprid effectively. After the incubation of 20 days, $P$. chrysosporium eliminate $21 \%$ and $51 \%$ of acetamiprid in two different media such as ligninolytic and non-ligninolytic, respectively.

Zhou L. Y. et al. (2014) previously reported that the nitrile hydratase enzyme of Ensifer meliloti CGMCC 7333 was a powerful tool to convert acetamiprid into the $\mathrm{N}$-amidoamine metabolite, which is unstable and further degrade to make intermediate chlorinated pyridyl methylmethanamine compound. Fascinatingly, Ensifer meliloti CGMCC7333 was also proficient at degrading thiacloprid into the $\mathrm{N}$-carbamoyl imine intermediate by using the same enzyme (Ge et al., 2014).

The biodegradation of imidacloprid using Trichoderma atroviride strain T23 and screening of transformants to achieve 


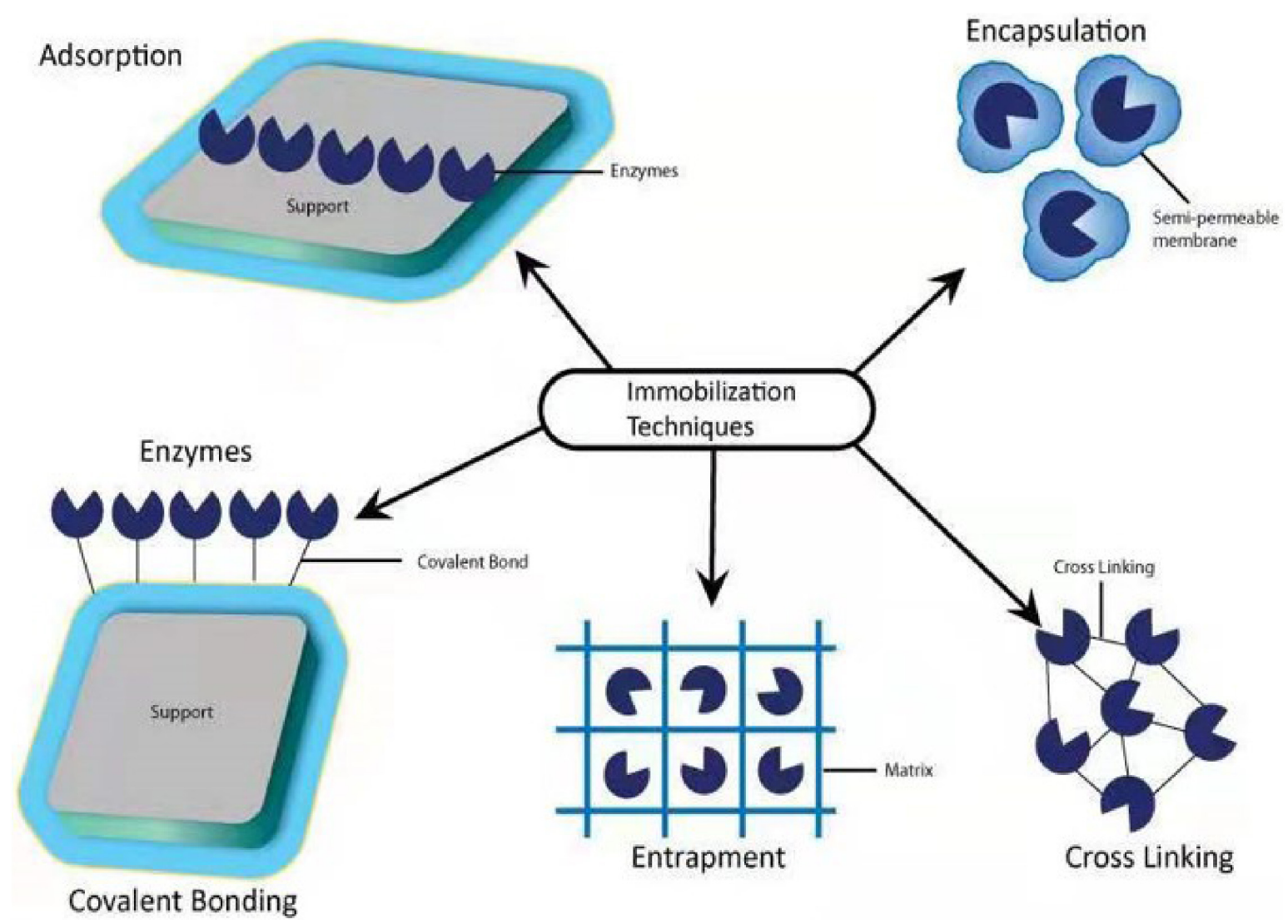

FIGURE 9 | Immobilization methods for neonicotinoid-degrading microbes and enzymes.

maximum degradation rate was investigated. REMI (restriction enzyme-mediated integration) technique was adopted for the construction of mutant strain. Plasmid pBluescript II KS$h p h$ (4334 bp) containing hygromycin ( $h p h)$ and ampicillin $(a m p)$ resistance genes was used. Finally, REMI mutants were confirmed by PCR and Southern hybridization analysis. Results revealed that total 174 transformants were developed from the wild $T$. atroviride strain T23. During sub-culturing, 21 colonies lost their resistance to hygromycin and the other 153 grew stably with a transformation frequency of $87.9 \%$. The efficiency of transformants for the biodegradation of imidacloprid was investigated by the colorimetric method. Among 153 transformants, 57\% of them showed maximum degradation ability compared to wild strain (He et al., 2014). For the bioremediation of acetamiprid in an agroecosystem, Wang et al. (2013a) isolated Pigmentiphaga sp. strain AAP-1 from polluted soil. The results demonstrated that bacterial strain degraded acetamiprid in soil efficiently. The bacterial community was also recovered from contaminated soil, by analysis of terminal (RFLP), after the incubation of Pigmentiphaga $s p$. strain AAP-1.

\section{Omics Approaches}

The biodegradation mechanism has certain limitations. It is successful at one location and may not be feasible in other places, and identifying the polluted sites is also quite time-consuming. Additionally, the mechanism that controls the growth and activity of microbial strains to degrade xenobiotics in field conditions is not well understood (Lovley, 2003). Therefore, laborious efforts are needed to make the degradation process effective, faster, quite efficient, and more suitable to act on a wide variety of organic and inorganic pollutants (Kumar Awasthi et al., 2020). By using molecular techniques to protect the environment, including genomics, transcriptomics, proteomics, and metabolomics plays a significant role in microbial habitats (Li et al., 2017).

These omics demonstrate extensive insights into the functional behavior of organisms by enhancing our knowledge of key biosynthetic processes and molecules such as genes, proteins, and metabolites. These approaches not only are used to investigate the crucial role of microbial species that regulate soil functions, enhance plant growth, and are used as a quorum sensing to understand the community composition to assign an ecological role but also provide behavioral information of cultured and uncultured microbial species and identify genes that actively participate in degradation process (Sharma et al., 2008; Festa et al., 2017; Malik et al., 2021). These omics also provide essential data about the genes and proteins involved in the degradation of pesticides and their metabolites (Rodríguez et al., 2020). Biodegradation genomics is used to identify 
TABLE 4 | Enzyme from different sources involved in the biodegradation of neonicotinoid insecticides.

\begin{tabular}{|c|c|c|c|c|}
\hline Target neonicotinoid & Enzymes & Source & Comments & References \\
\hline $\begin{array}{l}\text { Imidacloprid, } \\
\text { Thiamethoxam and } \\
\text { Dinotefuran }\end{array}$ & CYP6ER1 & Nilaparvata lugens & $\begin{array}{l}\text { Over-expressed in thiamethoxam-resistant and dinotefuran-resistant } \\
\text { strains }\end{array}$ & Pang et al., 2016 \\
\hline Imidacloprid & CYP6G1 & $\begin{array}{l}\text { Drosophila } \\
\text { melanogaster }\end{array}$ & An enzyme that produces toxic but easily excreted metabolites & $\begin{array}{l}\text { Fusetto et al., } \\
2017\end{array}$ \\
\hline Imidacloprid & CYP6CM1 & Bemisia tabaci & Bemisia tabaci resistant to imidacloprid lacks resistance to dinotefuran & $\begin{array}{l}\text { Hamada et al., } \\
2019\end{array}$ \\
\hline Imidacloprid & CYP353D1v2 & $\begin{array}{l}\text { Laodelphax } \\
\text { striatellus }\end{array}$ & Metabolize imidacloprid to 5 hydroxy-imidacloprid & Elzaki et al., 2017 \\
\hline Thiamethoxam & CYP6CY14 & Aphis gossypii & $\begin{array}{l}\text { RNA interference targeting CYP6CY14 increased the sensitivity of } \\
\text { resistant aphid to thiamethoxam }\end{array}$ & Wu et al., 2018 \\
\hline $\begin{array}{l}\text { Acetamiprid and } \\
\text { Thiacloprid }\end{array}$ & Nitrile hydratase & $\begin{array}{l}\text { Ensifer meliloti } \\
\text { CGMCC } 7333\end{array}$ & $\begin{array}{l}\text { Nitrile hydratase transformed the neonicotinoid compounds, and their } \\
\text { activity is increased by increasing the concentrations of } \\
\text { dichloromethane and hexane }\end{array}$ & $\begin{array}{l}\text { Zhao et al., } \\
2019 a\end{array}$ \\
\hline Acetamiprid & CYP5147A3 & $\begin{array}{l}\text { Phanerochaete } \\
\text { chrysosporium }\end{array}$ & $\begin{array}{l}\text { The degradation rate of acetamiprid significantly increased and } \\
\text { transform into two metabolites }\end{array}$ & $\begin{array}{l}\text { Wang et al., } \\
2019 \text { a }\end{array}$ \\
\hline Thiacloprid & Nitrile hydratase & $\begin{array}{l}\text { Variovorax } \\
\text { boronicumulans } \\
\text { CGMCC } 4969\end{array}$ & Degrade the thiacloprid and transform into amide metabolite & $\begin{array}{l}\text { Zhang et al., } \\
2012\end{array}$ \\
\hline Acetamiprid & Amidase & Pigmentiphaga sp. & $\begin{array}{l}\text { Amidase hydrolyze the C-N bond of acetamiprid and transform into } \\
\text { metabolite IM 1-4 }\end{array}$ & $\begin{array}{l}\text { Yang H. et al., } \\
2020\end{array}$ \\
\hline Nitenpyram & Cytochrome P450 & $\begin{array}{l}\text { Rhodococcus ruber } \\
\text { CGMCC } 17550\end{array}$ & $\begin{array}{l}\text { The cytochrome P450 mediate the hydroxylation pathway of nitenpyram } \\
\text { and 1-aminobenzotriazole strongly inhibited nitenpyram degradation }\end{array}$ & Dai et al., 2021 \\
\hline $\begin{array}{l}\text { Acetamiprid and } \\
\text { Imidacloprid }\end{array}$ & $\begin{array}{l}\text { Cytochrome P450 and } \\
\text { laccase }\end{array}$ & Trametes versicolor & $\begin{array}{l}\text { Cytochrome P450 play a vital role in the transformation of } \\
\text { neonicotinoids and proposed degradation pathway }\end{array}$ & Hu et al., 2021 \\
\hline Thiacloprid & Nitrile hydratase & $\begin{array}{l}\text { Proteobacteria and } \\
\text { Acidobacteria }\end{array}$ & $\begin{array}{l}\text { Biochar altered the soil properties and enhanced the degradation of } \\
\text { thiacloprid and activity of nitrile hydratase }\end{array}$ & $\begin{array}{l}\text { Zhang et al., } \\
2018 b\end{array}$ \\
\hline Imidacloprid & $\begin{array}{l}\text { Dehydrogenase and } \\
\text { ortho- diphenol oxidase }\end{array}$ & Commercial & $\begin{array}{l}\text { The grass layer in biobed enhances the activity of dehydrogenase and } \\
\text { ortho- diphenol oxidase which helps the dissipation of pesticides }\end{array}$ & $\begin{array}{l}\text { Delgado-Moreno } \\
\text { et al., } 2017\end{array}$ \\
\hline
\end{tabular}

effective genes in various microbial communities that encode specific enzymes used in biodegradation (Bharagava et al., 2019). Recently, Yang H. et al. (2020) identified novel amidase enzymes and genes from Pigmentiphaga sp. strain D-2 by using genomics tools involved in the degradation of acetamiprid. In another study, Guo et al. (2021) studied the degradation of acetamiprid by hydration pathway by Pseudaminobacter salicylatoxidans CGMCC 1.17248. Furthermore, this study explained that by gene cloning and overexpression, the identification of two different nitrile hydratase AnhA and AnhB simultaneously converted acetamiprid into $\{1-[(6-$ chloro-pyridin-3-ylmethyl)-methyl-amino]-ethylidene $\}$-urea

(IM 1-2). Proteomic analysis of microbial species provides an understanding of the protein pattern, function, interaction, and regulation (Jarnuczak et al., 2019).

The identification and physiological state of microbial communities can assist the understanding of genes that are associated with biodegradation mechanism and their regulation process (Kohl, 2020). Sun et al. (2018) identified two different NHase genes ( $c n h A$ and $p n h A)$ by Ensifer adhaerens CGMCC 6315 to degrade acetamiprid, while proteomic analysis showed that the upregulation expression of $p n h A$ genes improved degradation of acetamiprid ability. Transcriptomics is a prevailing tool used to assess microbial RNA expression and regulation on a whole organism level and provide an extensive collection of small regulatory non-coding RNAs
(Hör et al., 2018). Recently, Wang et al. (2021) provided a novel study for assessing of neonicotinoids on neuro-2a cells by lipidomics and metabolomics, which provides the ecological risk of neonicotinoids and contributes to investigating their residues in animals and humans in the future.

However, unraveling microbial interactions in complex microbial communities is a challenging task. Adopting these multi-omic approaches in co-existence with culture-based confirmation technique efficiently explains the microbial interactions affecting the biodegradation processes. It contributed to the future application and operation of environmental bioprocesses on a knowledge-based control (Chandran et al., 2020).

\section{Database Approaches}

Nowadays, bioinformatics and computational biology have been receiving wide attention in scientific research for the solution of biological problems. These techniques used biological principles with the fusion of mathematical, computer, and statistical principles to assist the development and application of bioremediation (Tomar, 2021). Besides the molecular and omics approaches, many online databases provide information regarding pesticide biodegradation by using microbes and their pathways (Nolte et al., 2018). The mainly used databases in the field of biodegradation are the University of Minnesota pathway prediction system (UM-PPS), microbial volatile organic 
compounds (mVOCs), University of Minnesota biocatalysts or biodegradation database (UM-BBD), biodegradation network molecular biology database (BioNeMo), pesticide target interaction database (PTID), microbial genome database (MBGD), biodegradative oxygenase's database (oxdbase), and biocyc and metacyc compatible with both Windows and Linux operating system (Hou et al., 2004; Effmert et al., 2012; Arora and Bae, 2014). UMBBD pathway forecast database shows the data regarding microbial biocatalytic reactions, biodegradation pathways, and metabolites achieved during the removal of pesticides by microbes (Dvořák et al., 2017).

University of Minnesota pathway prediction system provides information about the possible intermediates of pesticides, biocides, and pharmaceuticals. Various researchers such as environmental microbiologists, risk assessors, and analytical chemists used this database and discovered most related metabolites (Wicker et al., 2010). The mVOCs database provides information about compound identification and allows quick mass spectrum comparison. Moreover, it offers new insights into the generation of microbial volatiles, which helps in various fields such as quorum sensing and medical applications (Lemfack et al., 2018). The microbial genome database plays a significant role in the inspection at the genomic level used for estimating the positions of genes, ortholog recognition, and collection of paralog data (Parks et al., 2015). The biodegradative oxygenase's database was developed by the CSIR Institute of Microbial Technology, Chandigarh, India. This database stores information regarding oxygenase enzymes that take part in the degradation process from published literature and databases (Arora et al., 2009). Biodegradation network molecular biology databases have access to sequences barcoding for biodegradation genes and their transcription and regulation (Kumari and Kumar, 2021). For the biodegradation of thiamethoxam, a database approach was studied by $\mathrm{Wu}$ et al. (2021), and the biodegradation protein database including 17 sub-databases (alkb, benA, bph, bphA1, bphA2, carA, dbfA1, dxnA, dxnAdbfA1, glx, lip, mmox, mnp, npah, ppah, ppo, and genes of P450 enzyme) was downloaded from the FunGene protein database $^{2}$. Besides this, the pesticide degradation gene protein database was also recovered from the NCBI protein database for eight neonicotinoid pesticides, including acetamiprid, imidacloprid, thiamethoxam, clothianidin, dinotefuran, flonicamid, clothianidin, and nitenpyram.

\section{Immobilization Techniques}

Immobilization is considered the most efficient technique for utilizing microbial isolates in continuous mode (Ugwuodo and Nwagu, 2020). Immobilization stops the misplacement of microbial strains during uninterrupted operation and enhances the cell density, which plays a significant role in the degradation process. Moreover, the immobilized microbes can withstand extreme environmental stress such as temperature, $\mathrm{pH}$, and toxic compounds (Kurade et al., 2019). For immobilization, the support substances are vital as well as biocompatible with microbial cells and their enzymes. Different types of substances

${ }^{2}$ http://fungene.cme.msu.edu like organic (alginate, chitosan, agar, polyvinyl alcohol, collagen, cellulose, keratins, carrageenan, and chitin), inorganic (silica, alumina, iron oxides, and carbon-based materials), organicorganic hybrid, and organic-inorganic hybrid substances have been used to immobilize bacteria and other microbes (Horchani et al., 2012; Zdarta et al., 2019). Besides these substances, clay materials (bentonite, halloysite, kaolinite, montmorillonite, and sepiolite) and new support materials such as magnetic particles, mesoporous materials (zeolites, carbons, and sol-gel matrices), nanoparticles (nanogold, silver, iron, and graphene), ceramic materials (alumina, zirconia, titania, silica, iron oxide, and calcium phosphate), and electrospun materials are reported in for the immobilization of microbial cells and enzymes (Zdarta et al., 2018).

Among them, inorganic substances that have adequate mechanical strength in aggregation with synthetic or natural organic materials are more suitable for excessive biocompatibility (Wang Y. et al., 2020). There are different geometric shapes of immobilized materials such as beads (Liu et al., 2019), hollow cylinders (Lee et al., 2016), and core-shell structure beads that have been reported (Yu et al., 2019).

The immobilization technique can be done with the help of physical and chemical methods such as physical adsorption, entrapment, encapsulation, covalent bonding, and cross-linking (Wang W. et al., 2020; Figure 9). In physical adsorption, the microbial cells are attaching to the surface of the support by the poor van der Waals and via different interactions such as electrostatic, hydrophobic, and hydration, in which cells are vulnerable to the culture solution immediately (Sandhyarani, 2019).

For the process of entrapment, microbial cells are encapsulated within the polymeric matrix. Encapsulation maintained microbial strength with a semipermeable membrane capable of supplying nutrients and substrates between the carrier substances and culture media (Kumar et al., 2016). In all these methods, entrapment and encapsulation using organic or inorganic polymers is a ubiquitous method for separating bacterial cells from the growing environment (Jia et al., 2014). To remove imidacloprid residues in water, Ma et al. (2021a) synthesized a novel and efficient magnetic sludge biochar $\left(\mathrm{CoFe}_{2} \mathrm{O}_{4}\right)$ with the modification of graphene oxide. Kinetics, isotherms, thermodynamics, and environmental factors analysis demonstrated that both physisorption and chemisorption were involved in the imidacloprid adsorption onto graphene oxide metal sludge biochar. The adsorption capacity of $\mathrm{CoFe}_{2} \mathrm{O}_{4}$ ensured the magnetic sensitivity of graphene oxide magnetic sludge biochar, which enabled it to be easily separated from water solution and could be used to remove the residues of imidacloprid from polluted environment. In another study, Ma et al. (2021b) adopted another way to degrade imidacloprid in water by choosing sugarcane bagasse due to its higher adsorption capacity of $313 \mathrm{mg} / \mathrm{g}$ at $298 \mathrm{~K}$ synthesized in potassium hydroxide and other magnetic particles (iron/zinc, $\mathrm{Fe} / \mathrm{Zn})$. There are several factors such as characterization, kinetic, isotherm, thermodynamic, and environmental factors analyzed. These factors indicated that both chemisorption and physisorption were spontaneous, endothermic, and randomly 
increasing processes involved in imidacloprid adsorption. Furthermore, this study demonstrated that magnetic particles easily separated from the solution, which could be reused. This study suggested that magnetic particle-based sugarcane bagasse biochar is an effective, green, and sustainable adsorbent for neonicotinoid biodegradation.

To investigate acetamiprid and silica nanoparticle transportation in pure and biochar amended sands, Wang $\mathrm{H}$. et al. (2016) conducted an experiment. The results demonstrated that the retention of acetamiprid at neutral $\mathrm{pH}$ and less ionic strength was less in the pure sand compared to biochar amended sand. Moreover, due to their nonionic attributes, the acetamiprid cannot bond with the biochar by protonation or deprotonation, and the resulting sorption rate was not affected by environmental conditions. In another study, Gomaa et al. (2020) had immobilized Lysinobacillus macrolides strain MSR-H10 with sodium alginate for the biodegradation of acetamiprid in clay soil. The results reported that bacterial cells immobilized with sodium alginate degrade rapidly and effectively without lacking their efficiency. Recently, Dai et al. (2021) had isolated actinomycetes Rhodococcus ruber CGMCC 17550 from a nitenpyram production sewage treatment tank for surface water treatment. The cells of Rhodococcus ruber CGMCC 17550 were immobilized in calcium-alginate, which degraded nitenpyram up to $87.11 \%$ with the concentration of $100 \mathrm{mg} / \mathrm{L}$ in 8 days. By resulting the biodegradation of nitenpyram, it converts into their three metabolites by a novel hydroxylation pathway (1) (E)-1-((1-(methylamino)2-nitrovinyl) (pyridin-3-ylmethyl) amino) ethan-1-ol, (E)-6-chloro-3-((ethyl(1-(methylamino)-2-nitrovinyl) amino) methyl) pyridin-2-ol, and (E)-(6-chloropyridin-3-yl) (ethyl(1(methylamino)-2 nitrovinyl) amino) methanol. Further oxidation cleavage of (E)-(6-chloropyridin-3-yl) (ethyl(1(methylamino)-2 nitrovinyl) amino) methanol converts into (E)-N-ethyl- $N^{\prime}$-methyl-2-nitroethene-1,1-diamine (Figure 5).

Covalent binding and crosslinking are chemical methods for microbial immobilization based on covalent bonds between the functional groups present in the microbial cell wall and its support. Immobilization by the cross-linking process applies multifunctional reagents to encourage the development of a channel between functional groups on the external cell membrane (Giese et al., 2020). In covalent binding and cross-linking methods, whole microbial cells are vulnerable to chemicals and acute conditions, which may injure the cell surface and decline its metabolic activity. Therefore, crosslinking has been more victorious in the immobilization of non-viable microbial cells (Martins et al., 2013). Cross-linking has a wide range of acceptance for microbial immobilization and presents benefits like speed and simplicity compared to covalent bonding, and is challenging to control carefully (Mehrotra et al., 2021). By using covalent bonding and adsorption, Chen et al. (2019) had immobilized laccase enzyme with the support of wheat straw and peanut shells to remove nitenpyram in the agroecosystem. The results revealed that the successful application of immobilized laccase enzymes for the degradation of nitenpyram in agroecosystem has a strong and effective potential.
The half-life of the immobilized enzyme was reported to be higher than the soluble enzyme, with only a slight decrease in the catalytic activity of up to 12 consecutive cycles (Bhatt et al., 2020). The enzyme immobilization technique aims to enhance the stability of enzymes that depend on the structure, method of immobilization, and matrix material. Enzymes purified from diverse microbes can be a superior choice for large-scale pesticide biodegradation in a short time. The choice of immobilization technique in biodegradation plays a significant role with costeffective, stable performance, good mass transfer, high intensity, long lifespan, and environment friendly (Hameed and Ismail, 2020; Celik et al., 2021).

\section{CONCLUSION AND FUTURE PERSPECTIVES}

Due to the imprudent use of neonicotinoids throughout the world, their residues increase in the environment, causing severe threats for non-target organisms like bees. The biodegradation of neonicotinoid pesticides in the environment through microbes associated with their enzymes and genes in the field of molecular basis has come forth as an excellent option. There are many bioremediation techniques and strategies available to alleviate neonicotinoid risks. In the microbial degradation process, the elements including catabolic genes, enzymes, plasmids, proteins, mobile elements, and transposons play essential roles to catalyze novel biochemical pathways. Furthermore, omic approaches have the potential to forecast microbial communities and their metabolism in contaminated sites. These omic approaches also pay many benefactions to the logical identification of the potential microbes. These microbial technologies track novel microbes, providing new and excellent insights into their critical bio-degrative pathways at the molecular level. The immobilization of microbes with various carrier materials makes them more tolerant against the toxicity of hazardous pollutants. It provides a large specific area, strong adsorption ability, high porosity, and permeability of microorganisms. Recent advances in microbial technologies degradation of toxic compounds prediction systems have made tremendous and efficient advancements that allow virtual screening and toxicity profiles of hazardous pollutants. Except for these approaches, more attention is required to the effective use of genetic tools such as genetic libraries, genetic fingerprinting, radio respirometry, and micro autoradiography in neonicotinoid polluted environments. Besides, the progress of rapid genomic tools, bioinformatics tools, artificial intelligence, and system biology can be additionally used to inspect covered or invisible microbes in a polluted environment. Moreover, a large number of genetically modified organisms (GMOs) are required to construct because indigenous microbes are not active in every environment and GMOs play a crucial role in the biodegradation of xenobiotics. Various innovative techniques could be applied to produce GMOs, such as molecular cloning, horizontal transfer of DNA, electroporation and protoplast transformation, biolistic transformation, conjugation, and transformation of most capable microbial cells. To degrade different 
pesticide groups on an industrial scale, biochar production, enzymes production using fermentation chamber, and costeffective carrier materials used in bioreactor systems are seeking wide attention.

\section{AUTHOR CONTRIBUTIONS}

JL and GZ conceived the presented idea. SA prepared the original manuscript, figures, and tables. SA, JL, GZ, and DC contributed

\section{REFERENCES}

Acero, J. L., Real, F. J., Benitez, F. J., and Matamoros, E. (2019). Degradation of neonicotinoids by UV irradiation: kinetics and effect of real water constituents. Sep. Purif. Technol. 211, 218-226. doi: 10.1016/j.seppur.2018.09.076

Akoijam, R., and Singh, B. (2015). Biodegradation of imidacloprid in sandy loam soil by Bacillus aerophilus. Int. J. Environ. Anal. Chem. 95, 730-743. doi: 10.1080/03067319.2015.1055470

Anhalt, J. C., Moorman, T. B., and Koskinen, W. C. (2007). Biodegradation of imidacloprid by an isolated soil microorganism. J. Environ. Sci. Health B 42, 509-514. doi: 10.1080/03601230701391401

Annabi, A., Dhouib, I. B., Lamine, A. J., Golli, N. E., Gharbi, N., Fazâa, S. E., et al. (2015). Recovery by $\mathrm{N}$-acetylcysteine from subchronic exposure to imidacloprid-induced hypothalamic-pituitary-adrenal (HPA) axis tissues injury in male rats. Toxicol. Mech. Methods 25, 524-531. doi: 10.3109/15376516. 2015.1045663

Arora, P. K., and Bae, H. (2014). Integration of bioinformatics to biodegradation. Biol. Proced. 16, 1-10. doi: 10.1186/1480-9222-16-8

Arora, P. K., Kumar, M., Chauhan, A., Raghava, G. P., and Jain, R. K. (2009). OxDBase: a database of oxygenases involved in biodegradation. BMC Res. Notes 2:67. doi: 10.1186/1756-0500-2-67

Bailón-Salas, A. M., Medrano-Roldán, H., Valle-Cervantes, S., Ordaz-Díaz, L. A., Urtiz-Estrada, N., and Rojas-Contreras, J. A. (2017). Review of molecular techniques for the identification of bacterial communities in biological effluent treatment facilities at pulp and paper mills. BioResources 12, 4384-4409. doi: 10.15376/biores.12.2.bailon_salas

Berheim, E. H., Jenks, J. A., Lundgren, J. G., Michel, E. S., Grove, D., and Jensen, W. F. (2019). Effects of neonicotinoid insecticides on physiology and reproductive characteristics of captive female and fawn white-tailed deer. Sci. Rep. 9:4534. doi: 10.1038/s41598-019-40994-9

Bharagava, R. N., Purchase, D., Saxena, G., and Mulla, S. I. (2019). “Applications of metagenomics in microbial bioremediation of pollutants: from genomics to environmental cleanup," in Microbial Diversity in the Genomic Era, eds D. Surajit and D. H. Ranjan (Amsterdam: Elsevier), 459-477. doi: 10.1016/b9780-12-814849-5.00026-5

Bhatt, P., Bhatt, K., Huang, Y., Lin, Z., and Chen, S. (2020). Esterase is a powerful tool for the biodegradation of pyrethroid insecticides. Chemosphere 244:125507. doi: 10.1016/j.chemosphere.2019.125507

Bian, T., Zhu, X., Guo, J., Zhuang, Z., Cai, Z., and Zhao, X. (2018). Toxic effect of the novel chiral insecticide IPP and its biodegradation intermediate in nematode Caenorhabditis elegans. Ecotoxicol. Environ. Saf. 164, 604-610. doi: 10.1016/j.ecoenv.2018.08.059

Bonmatin, J.-M., Giorio, C., Girolami, V., Goulson, D., Kreutzweiser, D., Krupke, C., et al. (2015). Environmental fate and exposure; neonicotinoids and fipronil. Environ. Sci. Pollut. Res. 22, 35-67. doi: 10.1007/s11356-0143332-7

Cai, Z., Ma, J., Wang, J., Cai, J., Yang, G., and Zhao, X. (2016). Impact of the novel neonicotinoid insecticide Paichongding on bacterial communities in yellow loam and Huangshi soils. Environ. Sci. Pollut. Res. 23, 5134-5142. doi: 10.1007/ s11356-015-5733-7

Caron-Beaudoin, É, Viau, R., and Sanderson, J. T. (2018). ). Effects of neonicotinoid pesticides on promoter-specific aromatase (CYP19) expression in Hs578t breast cancer cells and the role of the VEGF pathway. Environ. Health Perspect. 126:047014. doi: 10.1289/ehp2698 to revising the manuscript. JL supervised the project. All authors approved it for publication.

\section{FUNDING}

This work was funded by National Natural Science Foundation of China (No. 32001948), Key Realm R\&D Program of Guangdong Province (2018B020205003), and Science and Technology Projects in Guangzhou (202102020911).

Casida, J. E. (2011). Neonicotinoid metabolism: compounds, substituents, pathways, enzymes, organisms, and relevance. J. Agric. Food Chem. 59, 2923 2931. doi: $10.1021 /$ jf102438c

Celik, S., Duman, N., Sayin, F., Akar, S. T., and Akar, T. (2021). Microbial cells immobilized on natural biomatrix as a new potential ecofriendly biosorbent for the biotreatment of reactive dye contamination. J. Water Process. Eng. 39:101731. doi: 10.1016/j.jwpe.2020.101731

Chandran, H., Meena, M., and Sharma, K. (2020). Microbial biodiversity and bioremediation assessment through omics approaches. Front. Environ. Chem. 1:570326. doi: 10.3389/fenvc

Chen, A., Li, W., Zhang, X., Shang, C., Luo, S., Cao, R., et al. (2021). Biodegradation and detoxification of neonicotinoid insecticide thiamethoxam by white-rot fungus Phanerochaete chrysosporium. J. Hazard. Mater. 417:126017. doi: 10. 1016/j.jhazmat.2021.126017

Chen, T., Dai, Y.-J., Ding, J.-F., Yuan, S., and Ni, J.-P. (2008). N-demethylation of neonicotinoid insecticide acetamiprid by bacterium Stenotrophomonas maltophilia CGMCC 1.1788. Biodegradation 19, 651-658. doi: 10.1007/s10532007-9170-2

Chen, X., Zhou, Q., Liu, F., Peng, Q., and Teng, P. (2019). Removal of nine pesticide residues from water and soil by biosorption coupled with degradation on biosorbent immobilized laccase. Chemosphere 233, 49-56. doi: 10.1016/j. chemosphere.2019.05.144

Cimino, A. M., Boyles, A. L., Thayer, K. A., and Perry, M. J. (2017). Effects of neonicotinoid pesticide exposure on human health: a systematic review. Environ. Health Perspect. 125, 155-162. doi: 10.1289/ehp515

Czaplicki, L. M., and Gunsch, C. K. (2016). Reflection on molecular approaches influencing state-of-the-art bioremediation design: culturing to microbial community fingerprinting to omics. J. Environ. Eng. 142:03116002. doi: 10. 1061/(asce)ee.1943-7870.0001141

Dai, Y.-J., Ji, W.-W., Chen, T., Zhang, W.-J., Liu, Z.-H., Ge, F., et al. (2010). Metabolism of the neonicotinoid insecticides acetamiprid and thiacloprid by the yeast Rhodotorula mucilaginosa strain IM-2. J. Agric. Food Chem. 58, 2419-2425. doi: 10.1021/jf903787s

Dai, Y.-J., Yuan, S., Ge, F., Chen, T., Xu, S.-C., and Ni, J.-P. (2006). Microbial hydroxylation of imidacloprid for the synthesis of highly insecticidal olefin imidacloprid. Appl. Microbiol. Biotechnol. 71, 927-934. doi: 10.1007/s00253005-0223-3

Dai, Z.-L., Yang, W.-L., Fan, Z.-X., Guo, L., Liu, Z.-H., and Dai, Y.-J. (2021). Actinomycetes Rhodococcus ruber CGMCC 17550 degrades neonicotinoid insecticide nitenpyram via a novel hydroxylation pathway and remediates nitenpyram in surface water. Chemosphere 270, 128670. doi: 10.1016/j. chemosphere.2020.128670

Delgado-Moreno, L., Nogales, R., and Romero, E. (2017). Biodegradation of high doses of commercial pesticide products in pilot-scale biobeds using olive-oil agroindustry wastes. J. Environ. Manage. 204, 160-169. doi: 10.1016/j.jenvman. 2017.08.032

Dvořák, P., Nikel, P. I., Damborský, J., and de Lorenzo, V. (2017). Bioremediation 3.0: engineering pollutant-removing bacteria in the times of systemic biology. Biotechnol. Adv. 35, 845-866. doi: 10.1016/j.biotechadv.2017.08.001

Effmert, U., Kalderás, J., Warnke, R., and Piechulla, B. (2012). Volatile mediated interactions between bacteria and fungi in the soil. J. Chem. Ecol. 38, 665-703. doi: 10.1007/s10886-012-0135-5

Elzaki, M. E. A., Miah, M. A., Wu, M., Zhang, H., Pu, J., Jiang, L., et al. (2017). Imidacloprid is degraded by CYP353D1v2, a cytochrome P450 overexpressed 
in a resistant strain of Laodelphax striatellus. Pest Manag. Sci. 73, 1358-1363. doi: $10.1002 / \mathrm{ps} .4570$

Encarnação, T., Santos, D., Ferreira, S., Valente, A. J., Pereira, J., Campos, M., et al. (2021). Removal of imidacloprid from water by microalgae Nannochloropsis sp. and its determination by a validated RP-HPLC method. Bull. Environ. Contam. Toxicol. 107, 131-139. doi: 10.1007/s00128-021-03228-1

Erguven, G. O., and Demirci, U. (2021). Using Ochrobactrum thiophenivorans and Sphingomonas melonis for bioremediation of Imidacloprid. Environ. Technol. Innov. 21:101236. doi: 10.1016/j.eti.2020.101236

Erguven, G. O., and Yildirim, N. (2019). The evaluation of imidacloprid remediation in soil media by two bacterial strains. Curr. Microbiol. 76, 14611466. doi: 10.1007/s00284-019-01774-w

Fairbrother, A., Purdy, J., Anderson, T., and Fell, R. (2014). Risks of neonicotinoid insecticides to honeybees. Environ. Toxicol. Chem. 33, 719-731. doi: 10.1002/ etc. 2527

Ferreira, L., Rosales, E., Danko, A. S., Sanromán, M. A., and Pazos, M. M. (2016). Bacillus thuringiensis a promising bacterium for degrading emerging pollutants. Process. Saf. Environ. Prot. 101, 19-26. doi: 10.1016/j.psep.2015.05. 003

Festa, S., Coppotelli, B. M., Madueño, L., Loviso, C. L., Macchi, M., Neme Tauil, R. M., et al. (2017). Assigning ecological roles to the populations belonging to a phenanthrene-degrading bacterial consortium using omic approaches. PLoS One 12:e0184505. doi: 10.1371/journal.pone.0184505

Fusetto, R., Denecke, S., Perry, T., Richard, A., and Batterham, P. (2017). Partitioning the roles of CYP6G1 and gut microbes in the metabolism of the insecticide imidacloprid in Drosophila melanogaster. Sci. Rep. 7:11339. doi: 10.1038/s41598-017-09800-2

García-Galán, M. J., Monllor-Alcaraz, L. S., Postigo, C., Uggetti, E., de Alda, M. L., Díez-Montero, R., et al. (2020). Microalgae-based bioremediation of water contaminated by pesticides in peri-urban agricultural areas. Environ. Pollut. 265,:114579. doi: 10.1016/j.envpol.2020.114579

Ge, F., Zhou, L.-Y., Wang, Y., Ma, Y., Zhai, S., Liu, Z.-H., et al. (2014). Hydrolysis of the neonicotinoid insecticide thiacloprid by the N2-fixing bacterium Ensifer meliloti CGMCC 7333. Int. Biodeter. Biodegr. 93, 10-17. doi: 10.1016/j.ibiod. 2014.05.001

Gibbons, D., Morrissey, C., and Mineau, P. (2015). A review of the direct and indirect effects of neonicotinoids and fipronil on vertebrate wildlife. Environ. Sci. Pollut. Res. 22, 103-118. doi: 10.1007/s11356-014-3180-5

Giese, E. C., Silva, D. D., Costa, A. F., Almeida, S. G., and Dussán, K. J. (2020). Immobilized microbial nanoparticles for biosorption. Crit. Rev. Biotechnol. 40, 653-666. doi: 10.1080/07388551.2020.1751583

Gomaa, I. M., Saad, M. M., Mahmoud, H. A., and Abo-Koura, H. A. (2020). Biodegradation of Acetamiprid by both free and immobilized Lysinobacillus macrolides strain MSR-H10 in soil. Int. J. Sci. Res. Sustain. Dev. 3, 1-18. doi: 10.21698/ijsrsd.2020.131131

Guo, L., Dai, Z., Guo, J., Yang, W., Ge, F., and Dai, Y. (2020). Oligotrophic bacterium Hymenobacter latericoloratus CGMCC 16346 degrades the neonicotinoid imidacloprid in surface water. $A M B$ Express 10, 1-13. doi: 10.1186/s13568-019-0942-y

Guo, L., Fang, W.-W., Guo, L.-L., Yao, C.-F., Zhao, Y.-X., Ge, F., et al. (2019). Biodegradation of the neonicotinoid insecticide acetamiprid by actinomycetes Streptomyces canus CGMCC 13662 and characterization of the novel nitrile hydratase involved. J. Agric. Food Chem. 67, 5922-5931. doi: 10.1021/acs.jafc. 8 b06513

Guo, L., Yang, W., Cheng, X., Fan, Z., Chen, X., Ge, F., et al. (2021). Degradation of neonicotinoid insecticide acetamiprid by two different nitrile hydratases of Pseudaminobacter salicylatoxidans CGMCC 1.17248. Int. Biodeter. Biodegr. 157:105141. doi: 10.1016/j.ibiod.2020.105141

Gupta, M., Mathur, S., Sharma, T. K., Rana, M., Gairola, A., Navani, N. K., et al. (2016). A study on metabolic prowess of Pseudomonas sp. RPT 52 to degrade imidacloprid, endosulfan and coragen. J. Hazard. Mater. 301, 250-258. doi: 10.1016/j.jhazmat.2015.08.055

Gupta, S., Gajbhiye, V., and Gupta, R. (2008). Soil dissipation and leaching behavior of a neonicotinoid insecticide thiamethoxam. Bull. Environ. Contam. Toxicol. 80, 431-437. doi: 10.1007/s00128-008-9420-y

Halsch, C. A., Code, A., Hoyle, S. M., Fordyce, J. A., Baert, N., and Forister, M. L. (2020). Pesticide contamination of milkweeds across the agricultural, urban, and open spaces of low-elevation northern California. Front. Ecol. Evol. 8:162. doi: $10.3389 /$ fevo. 2020.00162

Hamada, A., Wahl, G. D., Nesterov, A., Nakao, T., Kawashima, M., and Banba, S. (2019). Differential metabolism of imidacloprid and dinotefuran by Bemisia tabaci CYP6CM1 variants. Pestic. Biochem. Physiol. 159, 27-33. doi: 10.1016/j. pestbp.2019.05.011

Hameed, B. B., and Ismail, Z. Z. (2020). New application of Orchis mascula as a biocarrier for immobilization of mixed cells for biodegradation and detoxification of reactive azo dyes. Environ. Sci. Pollut. Res. 27, 38732-38744. doi: 10.1007/s11356-020-09984-7

Han, W., Tian, Y., and Shen, X. (2018). Human exposure to neonicotinoid insecticides and the evaluation of their potential toxicity: an overview. Chemosphere 192, 59-65. doi: 10.1016/j.chemosphere.2017.10.149

Hano, T., Ito, K., Ohkubo, N., Sakaji, H., Watanabe, A., Takashima, K., et al. (2019). Occurrence of neonicotinoids and fipronil in estuaries and their potential risks to aquatic invertebrates. Environ. Pollut. 252, 205-215. doi: 10.1016/j.envpol. 2019.05.067

Harry-Asobara, J. L., and Kamei, I. (2019). Indirect bacterial effect enhanced less recovery of neonicotinoids by improved activities of white-rot fungus Phlebia brevispora. J. Microbiol. Biotechnol. 29, 809-812. doi: 10.4014/jmb.1809. 09051

He, X., Wubie, A. J., Diao, Q., Li, W., Xue, F., Guo, Z., et al. (2014). Biodegradation of neonicotinoid insecticide, imidacloprid by restriction enzyme mediated integration (REMI) generated Trichoderma mutants. Chemosphere 112, 526530. doi: 10.1016/j.chemosphere.2014.01.023

Hegde, D. R., Manoharan, T., and Sridar, R. (2017). Identification and characterization of bacterial isolates and their role in the degradation of neonicotinoid insecticide thiamethoxam. J. Pure Appl. Microbiol. 11, 393-400. doi: 10.22207/JPAM.11.1.51

Hör, J., Gorski, S. A., and Vogel, J. (2018). Bacterial RNA biology on a genome scale. Mol. Cell. 70, 785-799. doi: 10.1016/j.molcel.2017.12.023

Horchani, H., Aissa, I., Ouertani, S., Zarai, Z., Gargouri, Y., and Sayari, A. (2012). Staphylococcal lipases: biotechnological applications. J. Mol. Catal., B Enzym. 76, 125-132. doi: 10.1016/j.molcatb.2011.11.018

Hou, B. K., Ellis, L. B., and Wackett, L. P. (2004). Encoding microbial metabolic logic: predicting biodegradation. J. Ind. Microbiol. Biotechnol. 31, 261-272. doi: 10.1007/s10295-004-0144-7

Hu, G., Zhao, Y., Liu, B., Song, F., and You, M. (2013). Isolation of an indigenous imidacloprid-degrading bacterium and imidacloprid bioremediation under simulated in situ and ex situ conditions. J. Microbiol. Biotechnol. 23, 1617-1626. doi: 10.4014/jmb.1305.05048

Hu, K., Barbieri, M. V., López-García, E., Postigo, C., de Alda, M. L., Caminal, G., et al. (2021). Fungal degradation of selected medium to highly polar pesticides by Trametes versicolor kinetics, biodegradation pathways, and ecotoxicity of treated waters. Anal. Bioanal. Chem. doi: 10.1007/s00216-02103267-x

Hussain, S., Hartley, C. J., Shettigar, M., and Pandey, G. (2016). Bacterial biodegradation of neonicotinoid pesticides in soil and water systems. FEMS Microbiol. Lett. 363:fnw252. doi: 10.1093/femsle/fnw252

Jarnuczak, A. F., Ternent, T., and Vizcaíno, J. A. (2019). "Quantitative proteomics data in the public domain: challenges and opportunities," in Mass Spectrometry of Proteins, eds C. Evans, P. Wright, and J. Noirel (Berlin: Springer), 217-235. doi: 10.1007/978-1-4939-9232-4_14

Jayaraj, R., Megha, P., and Sreedev, P. (2016). Organochlorine pesticides, their toxic effects on living organisms and their fate in the environment. Interdiscip. Toxicol. 9:90. doi: 10.1515/intox-2016-0012

Jia, F., Narasimhan, B., and Mallapragada, S. (2014). Materials-based strategies for multi-enzyme immobilization and co-localization: a review. Biotechnol. Bioeng. 111, 209-222. doi: 10.1002/bit.25136

John, E. M., Varghese, E. M., Krishnasree, N., and Jisha, M. (2018). In situ bioremediation of chlorpyrifos by Klebsiella sp. isolated from pesticide contaminated agricultural soil. Int. J. Curr. Microbiol. Appl. Sci. 7, 1418-1429. doi: 10.20546/ijcmas.2018.703.170

Kandil, M. M., Trigo, C., Koskinen, W. C., and Sadowsky, M. J. (2015). Isolation and characterization of a novel imidacloprid-degrading Mycobacterium sp. strain MK6 from an Egyptian soil. J. Agric. Food Chem. 63, 4721-4727. doi: 10.1021/acs.jafc.5b00754 
Kanjilal, T., Bhattacharjee, C., and Datta, S. (2016). Utilization of S. aureus strain $502 \mathrm{~A}$ in biodegradation of insecticide acetamiprid from wetland wastewater. Desalin. Water Treat. 57, 13190-13206. doi: 10.1080/19443994.2015.1056839

Kohl, K. D. (2020). Ecological and evolutionary mechanisms underlying patterns of phylosymbiosis in host-associated microbial communities. Philos. Trans. R. Soc. B 375:20190251. doi: 10.1098/rstb.2019.0251

Kumar, G., Mudhoo, A., Sivagurunathan, P., Nagarajan, D., Ghimire, A., Lay, C.H., et al. (2016). Recent insights into the cell immobilization technology applied for dark fermentative hydrogen production. Bioresour. Technol. 219, 725-737. doi: 10.1016/j.biortech.2016.08.065

Kumar, S. S., Ghosh, P., Malyan, S. K., Sharma, J., and Kumar, V. (2019). A comprehensive review on enzymatic degradation of the organophosphate pesticide malathion in the environment. J. Environ. Sci. Health C. 37, 288-329. doi: 10.1080/10590501.2019.1654809

Kumar Awasthi, M., Ravindran, B., Sarsaiya, S., Chen, H., Wainaina, S., Singh, E., et al. (2020). Metagenomics for taxonomy profiling: tools and approaches. Bioengineered 11, 356-374. doi: 10.1080/21655979.2020.1736238

Kumari, P., and Kumar, Y. (2021). "Bioinformatics and computational tools in bioremediation and biodegradation of environmental pollutants," in Bioremediation for Environmental Sustainability, eds V. Kumar, G. Saxena, and M. P. Shah (Amsterdam: Elsevier), 421-444.

Kurade, M. B., Waghmode, T. R., Xiong, J.-Q., Govindwar, S. P., and Jeon, B.-H. (2019). Decolorization of textile industry effluent using immobilized consortium cells in upflow fixed bed reactor. J. Clean. Prod. 213, 884-891. doi: 10.1016/j.jclepro.2018.12.218

Lee, S. H., Lee, S., Lee, K., Nahm, C. H., Kwon, H., Oh, H.-S., et al. (2016). More efficient media design for enhanced biofouling control in a membrane bioreactor: quorum quenching bacteria entrapping hollow cylinder. Environ. Sci. Technol. 50, 8596-8604. doi: 10.1021/acs.est.6b01221

Lemfack, M. C., Gohlke, B.-O., Toguem, S. M. T., Preissner, S., Piechulla, B., and Preissner, R. (2018). mVOC 2.0: a database of microbial volatiles. Nucleic Acids Res. 46, D1261-D1265. doi: 10.1093/nar/gkx1016

Li, C., Xia, F., Zhang, Y., Chang, C. C., Wei, D., and Wei, L. (2017). Molecular biological methods in environmental engineering. Water Environ. Res. 89, 942-959. doi: 10.2175/106143017x15023776270197

Li, H., Qiu, Y., Yao, T., Ma, Y., Zhang, H., Yang, X., et al. (2020). Evaluation of seven chemical pesticides by mixed microbial culture (PCS-1): degradation ability, microbial community, and Medicago sativa phytotoxicity. J. Hazard. Mater. 389:121834. doi: 10.1016/j.jhazmat.2019.121834

Li, Z. (2021). Improving screening model of pesticide risk assessment in surface soils: considering degradation metabolites. Ecotoxicol. Environ. Saf. 222:112490. doi: 10.1016/j.ecoenv.2021.112490

Liao, X., Jin, R., Zhang, X., Ali, E., Mao, K., Xu, P., et al. (2019). Characterization of sulfoxaflor resistance in the brown planthopper, Nilaparvata lugens (Stål). Pest Manag. Sci. 75, 1646-1654. doi: 10.1002/ps.5282

Liu, J., Eng, C. Y., Ho, J. S., Chong, T. H., Wang, L., Zhang, P., et al. (2019). Quorum quenching in anaerobic membrane bioreactor for fouling control. Water Res. 156, 159-167. doi: 10.1016/j.watres.2019.03.029

Lou, Y., Xu, Y., Chai, Z., Shao, X., Zhao, G., and Li, Z. (2015). Organocatalytic Michael addition of 2-nitro methylene imidazolidines to $\alpha, \beta$-unsaturated aldehydes: concise synthesis of chiral insecticide Paichongding. Tetrahedron 71 , 6651-6658. doi: 10.1016/j.tet.2015.07.056

Lovley, D. R. (2003). Cleaning up with genomics: applying molecular biology to bioremediation. Nat. Rev. Microbiol. 1, 35-44. doi: 10.1038/nrmicro731

Lu, T.-Q., Mao, S.-Y., Sun, S.-L., Yang, W.-L., Ge, F., and Dai, Y.-J. (2016). Regulation of hydroxylation and nitroreduction pathways during metabolism of the neonicotinoid insecticide imidacloprid by Pseudomonas putida. J. Agric. Food Chem. 64, 4866-4875. doi: 10.1021/acs.jafc.6b01376

Ma, Y., Qi, Y., Yang, L., Wu, L., Li, P., Gao, F., et al. (2021a). Adsorptive removal of imidacloprid by potassium hydroxide activated magnetic sugarcane bagasse biochar: adsorption efficiency, mechanism and regeneration. J. Clean. Prod. 292:126005. doi: 10.1016/j.jclepro.2021.126005

Ma, Y., Wu, L., Li, P., Yang, L., He, L., Chen, S., et al. (2021b). A novel, efficient and sustainable magnetic sludge biochar modified by graphene oxide for environmental concentration imidacloprid removal. J. Hazard. Mater. 407:124777. doi: 10.1016/j.jhazmat.2020.124777

Ma, Y., Zhai, S., Mao, S. Y., Sun, S. L., Wang, Y., Liu, Z. H., et al. (2014). Co-metabolic transformation of the neonicotinoid insecticide imidacloprid by the new soil isolate Pseudoxanthomonas indica CGMCC 6648. J. Environ. Sci. Health B. 49, 661-670. doi: 10.1080/03601234.2014.922766

Malik, G., Arora, R., Chaturvedi, R., and Paul, M. S. (2021). Implementation of genetic engineering and novel omics approaches to enhance bioremediation: a focused review. Bull. Environ. Contam. Toxicol. doi: 10.1007/s00128-02103218-3

Malla, M. A., Dubey, A., Yadav, S., Kumar, A., Hashem, A., and Abd Allah, E. F. (2018). Understanding and designing the strategies for the microbe-mediated remediation of environmental contaminants using omics approaches. Front. Microbiol. 9:1132. doi: 10.3389/fmicb.2018.01132

Martins, S. C. S., Martins, C. M., Fiúza, L. M. C. G., and Santaella, S. T. (2013). Immobilization of microbial cells: a promising tool for treatment of toxic pollutants in industrial wastewater. Afr. J. Biotechnol. 12, 4412-4418. doi: 10.5897/ajb12.2677

Mehrotra, T., Dev, S., Banerjee, A., Chatterjee, A., Singh, R., and Aggarwal, S. (2021). Use of immobilized bacteria for environmental bioremediation: a review. J. Environ. Chem. Eng. 9, 105920. doi: 10.1016/j.jece.2021. 105920

Menon, M., Mohanraj, R., and Sujata, W. (2021). Monitoring of neonicotinoid pesticides in water-soil systems along the agro-landscapes of the cauvery delta region, South India. Bull. Environ. Contam. Toxicol. 106, 1065-1070. doi: 10.1007/s00128-021-03233-4

Mitchell, E. A., Mulhauser, B., Mulot, M., Mutabazi, A., Glauser, G., and Aebi, A. (2017). A worldwide survey of neonicotinoids in honey. Science 358, 109-111. doi: 10.1126/science.aan3684

Mohammed, Y. M., and Badawy, M. E. (2017). Biodegradation of imidacloprid in liquid media by an isolated wastewater fungus Aspergillus terreus YESM3. J. Environ. Sci. Health B. 52, 752-761. doi: 10.1080/03601234.2017.1356666

Monsalvo, V., Garcia-Mancha, N., Puyol, D., Mohedano, A., and Rodriguez, J. (2014). Anaerobic biodegradability of mixtures of pesticides in an expanded granular sludge bed reactor. Water Sci. Technol. 69, 532-538. doi: 10.2166/wst. 2013.739

Mori, T., Ohno, H., Ichinose, H., Kawagishi, H., and Hirai, H. (2021). Whiterot fungus Phanerochaete chrysosporium metabolizes chloropyridinyl-type neonicotinoid insecticides by an N-dealkylation reaction catalyzed by two cytochrome P450s. J. Hazard. Mater. 402:123831. doi: 10.1016/j.jhazmat.2020. 123831

Mori, T., Wang, J., Tanaka, Y., Nagai, K., Kawagishi, H., and Hirai, H. (2017). Bioremediation of the neonicotinoid insecticide clothianidin by the white-rot fungus Phanerochaete sordida. J. Hazard. Mater. 321, 586-590. doi: 10.1016/j. jhazmat.2016.09.049

Morrissey, C. A., Mineau, P., Devries, J. H., Sanchez-Bayo, F., Liess, M., Cavallaro, M. C., et al. (2015). Neonicotinoid contamination of global surface waters and associated risk to aquatic invertebrates: a review. Environ. Int. 74, 291-303. doi: 10.1016/j.envint.2014.10.024

Muerdter, C. P., and LeFevre, G. H. (2019). Synergistic Lemna duckweed and microbial transformation of imidacloprid and thiacloprid neonicotinoids. Environ. Sci. Technol. Lett. 6, 761-767. doi: 10.1021/acs.estlett.9b0 0638

Mulligan, R. A., Tomco, P. L., Howard, M. W., Schempp, T. T., Stewart, D. J., Stacey, P. M., et al. (2016). Aerobic versus anaerobic microbial degradation of clothianidin under simulated california rice field conditions. J. Agric. Food Chem. 64, 7059-7067. doi: 10.1021/acs.jafc.6b02055

Nolte, T. M., Pinto-Gil, K., Hendriks, A. J., Ragas, A. M., and Pastor, M. (2018). Quantitative structure-activity relationships for primary aerobic biodegradation of organic chemicals in pristine surface waters: starting points for predicting biodegradation under acclimatization. Environ. Sci. Proc. Imp. 20, 157-170. doi: 10.1039/c7em00375g

Pandey, G., Dorrian, S. J., Russell, R. J., and Oakeshott, J. G. (2009). Biotransformation of the neonicotinoid insecticides imidacloprid and thiamethoxam by Pseudomonas sp. 1G. Biochem. Biophys. Res. Commun. 380, 710-714. doi: 10.1016/j.bbrc.2009.01.156

Pang, R., Chen, M., Liang, Z., Yue, X., Ge, H., and Zhang, W. (2016). Functional analysis of CYP6ER1, a P450 gene associated with imidacloprid resistance in Nilaparvata lugens. Sci. Rep. 6:349992. doi: 10.1038/srep34992

Pang, S., Lin, Z., Zhang, W., Mishra, S., Bhatt, P., and Chen, S. (2020). Insights into the microbial degradation and biochemical mechanisms of neonicotinoids. Front. Microbiol. 11:868. doi: 10.3389/fmicb.2020.00868 
Parks, D. H., Imelfort, M., Skennerton, C. T., Hugenholtz, P., and Tyson, G. W. (2015). CheckM: assessing the quality of microbial genomes recovered from isolates, single cells, and metagenomes. Genome Res. 25, 1043-1055. doi: 10. $1101 /$ gr.186072.114

Parte, S. G., and Kharat, A. S. (2019). Aerobic degradation of clothianidin to 2chloro-methyl thiazole and methyl 3-(thiazole-yl) methyl guanidine produced by Pseudomonas stutzeri smk. J. Environ. Public Health 2019, 1-12. doi: 10. 1155/2019/4807913

Parween, T., Bhandari, P., Jan, S., and Raza, S. (2016). "Interaction between pesticide and soil microorganisms and their degradation: a molecular approach," in Plant, Soil and Microbes, eds K. Hakeem and M. Akhtar (Cham: Springer), 23-43. doi: 10.1007/978-3-319-29573-2_2

Peña, A., Rodríguez-Liébana, J., and Mingorance, M. (2011). Persistence of two neonicotinoid insecticides in wastewater, and in aqueous solutions of surfactants and dissolved organic matter. Chemosphere 84, 464-470. doi: 10. 1016/j.chemosphere.2011.03.039

Phugare, S. S., and Jadhav, J. P. (2015). Biodegradation of acetamiprid by isolated bacterial strain Rhodococcus sp. $\mathrm{BCH} 2$ and toxicological analysis of its metabolites in silkworm (Bombax mori). Clean (Weinh). 43, 296-304. doi: 10.1002/clen.201200563

Phugare, S. S., Kalyani, D. C., Gaikwad, Y. B., and Jadhav, J. P. (2013). Microbial degradation of imidacloprid and toxicological analysis of its biodegradation metabolites in silkworm (Bombyx mori). Chem. Eng. J. 230, 27-35. doi: 10.1016/ j.cej.2013.06.042

Pietrzak, D., Kania, J., Kmiecik, E., Malina, G., and Wạtor, K. (2020). Fate of selected neonicotinoid insecticides in soil-water systems: current state of the art and knowledge gaps. Chemosphere 255:126981. doi: 10.1016/j.chemosphere. 2020.126981

Pisa, L. W., Amaral-Rogers, V., Belzunces, L. P., Bonmatin, J.-M., Downs, C. A., Goulson, D., et al. (2015). Effects of neonicotinoids and fipronil on non-target invertebrates. Environ. Sci. Pollut. Res. 22, 68-102. doi: 10.1007/s11356-0143471-x

Prosenc, F., Piechocka, J., Škufca, D., Heath, E., Bulc, T. G., Istenič, D., et al. (2021). Microalgae-based removal of contaminants of emerging concern: mechanisms in Chlorella vulgaris and mixed algal-bacterial cultures. J. Hazard. Mater. 418:126284. doi: 10.1016/j.jhazmat.2021.126284

Racar, M., Dolar, D., Karadakić, K., Čavarović, N., Glumac, N., Ašperger, D., et al. (2020). Challenges of municipal wastewater reclamation for irrigation by MBR and NF/RO: physico-chemical and microbiological parameters, and emerging contaminants. Sci. Total Environ. 722:137959. doi: 10.1016/j.scitotenv.2020. 137959

Rana, S., Jindal, V., Mandal, K., Kaur, G., and Gupta, V. (2015). Thiamethoxam degradation by Pseudomonas and Bacillus strains isolated from agricultural soils. Environ. Monit. Assess. 187, 1-9. doi: 10.1007/s10661-015-4532-4

Rodríguez, A., Castrejón-Godínez, M. L., Salazar-Bustamante, E., Gama-Martínez, Y., Sánchez-Salinas, E., Mussali-Galante, P., et al. (2020). Omics approaches to pesticide biodegradation. Curr. Microbiol. 77, 545-563. doi: 10.1007/s00284020-01916-5

Rodríguez-Castillo, G., Molina-Rodríguez, M., Cambronero-Heinrichs, J. C., Quirós-Fournier, J. P., Lizano-Fallas, V., Jiménez-Rojas, C., et al. (2019). Simultaneous removal of neonicotinoid insecticides by a microbial degrading consortium: detoxification at reactor scale. Chemosphere 235, 1097-1106. doi: 10.1016/j.chemosphere.2019.07.004

Sabourmoghaddam, N., Zakaria, M. P., and Omar, D. (2015). Evidence for the microbial degradation of imidacloprid in soils of Cameron Highlands. J. Saudi Soc. Agric. Sci. 14, 182-188. doi: 10.1016/j.jssas.2014.03.002

Sandhyarani, N. (2019). "Surface modification methods for electrochemical biosensors," in Electroc. Biosens, ed. A. A. Ensafi (Amsterdam: Elsevier), 45-75. doi: 10.1016/b978-0-12-816491-4.00003-6

Schulz, R., Bub, S., Petschick, L. L., Stehle, S., and Wolfram, J. (2021). Applied pesticide toxicity shifts toward plants and invertebrates, even in GM crops. Science 372, 81-84. doi: 10.1126/science.abe1148

Shahid, M., Khan, M. S., Ahmed, B., Syed, A., and Bahkali, A. H. (2021). Physiological disruption, structural deformation and low grain yield induced by neonicotinoid insecticides in chickpea: a long term phytotoxicity investigation. Chemosphere 262:128388. doi: 10.1016/j.chemosphere.2020.12

Shao, X., Zhang, W., Peng, Y., Li, Z., Tian, Z., and Qian, X. (2008). cisNitromethylene neonicotinoids as new nicotinic family: synthesis, structural diversity, and insecticidal evaluation of hexahydroimidazo $[1,2-\alpha]$ pyridine. Bioorganic Med. Chem. Lett. 18, 6513-6516. doi: 10.1016/j.bmcl.2008.10.048

Sharma, B., Dangi, A. K., and Shukla, P. (2018). Contemporary enzyme based technologies for bioremediation: a review. J. Environ. Manage. 210, 10-22. doi: 10.1016/j.jenvman.2017.12.075

Sharma, P., Kumari, H., Kumar, M., Verma, M., Kumari, K., Malhotra, S., et al. (2008). From bacterial genomics to metagenomics: concept, tools and recent advances. Indian J. Microbiol. 48, 173-194. doi: 10.1007/s12088-008-0031-4

Sharma, S., Singh, B., and Gupta, V. (2014b). Biodegradation of imidacloprid by consortium of two soil isolated Bacillus sp. Bull. Environ. Contam. Toxicol. 93, 637-642. doi: 10.1007/s00128-014-1386-3

Sharma, S., Singh, B., and Gupta, V. (2014a). Assessment of imidacloprid degradation by soil-isolated Bacillus alkalinitrilicus. Environ. Monit. Assess. 186, 7183-7193. doi: 10.1007/s10661-014-3919-y

Sheets, L. P., Li, A. A., Minnema, D. J., Collier, R. H., Creek, M. R., and Peffer, R. C. (2016). A critical review of neonicotinoid insecticides for developmental neurotoxicity. Crit. Rev. Toxicol. 46, 153-190. doi: 10.3109/10408444.2015. 1090948

Shi, Z., Dong, W., Xin, F., Liu, J., Zhou, X., Xu, F., et al. (2018). Characteristics and metabolic pathway of acetamiprid biodegradation by Fusarium sp. strain CS-3 isolated from soil. Biodegradation 29, 593-603. doi: 10.1007/s10532-0189855-8

Simon-Delso, N., Amaral-Rogers, V., Belzunces, L. P., Bonmatin, J.-M., Chagnon, M., Downs, C., et al. (2015). Systemic insecticides (neonicotinoids and fipronil): trends, uses, mode of action and metabolites. Environ. Sci. Pollut. Res. 22, 5-34. doi: 10.1007/s11356-014-3470-y

Sinha, S., Chattopadhyay, P., Pan, I., Chatterjee, S., Chanda, P., Bandyopadhyay, D., et al. (2009). Microbial transformation of xenobiotics for environmental bioremediation. Afr. J. Biotechnol. 8, 6016-6027. doi: 10.5897/ajb09.740

Sparks, T. C., and Nauen, R. (2015). IRAC: mode of action classification and insecticide resistance management. Pestic. Biochem. Physiol. 121, 122-128. doi: 10.1016/j.pestbp.2014.11.014

Sun, S., Fan, Z., Zhao, Y., Guo, L., and Dai, Y. (2018). A novel nutrient deprivation-induced neonicotinoid insecticide acetamiprid degradation by Ensifer adhaerens CGMCC 6315. J. Agric. Food Chem. 67, 63-71. doi: 10.1021/ acs.jafc.8b06154

Sun, S.-L., Yang, W.-L., Guo, J.-J., Zhou, Y.-N., Rui, X., Chen, C., et al. (2017). Biodegradation of the neonicotinoid insecticide acetamiprid in surface water by the bacterium Variovorax boronicumulans CGMCC 4969 and its enzymatic mechanism. Rsc Adv. 7, 25387-25397. doi: 10.1039/c7ra01501a

Tang, H., Li, J., Hu, H., and Xu, P. (2012). A newly isolated strain of Stenotrophomonas sp. hydrolyzes acetamiprid, a synthetic insecticide. Process Biochem. 47, 1820-1825. doi: 10.1016/j.procbio.2012.06.008

Thompson, D. A., Lehmler, H.-J., Kolpin, D. W., Hladik, M. L., Vargo, J. D., Schilling, K. E., et al. (2020). A critical review on the potential impacts of neonicotinoid insecticide use: current knowledge of environmental fate, toxicity, and implications for human health. Environ. Sci. Proc. Imp. 22, 13151346. doi: 10.1039/c9em00586b

Tomar, J. (2021). "'Bioinformatics: a new insight tool to deal with environment management," in Appl. Microbiol. Biotechnol, eds A. Singh, S. Srivastava, D. Rathore, and D. Pant (Cham: Springer), 155-184. doi: 10.1007/978-981-157493- 1

Toolabi, A., Malakootian, M., Ghaneian, M. T., Esrafili, A., Ehrampoush, M. H., Tabatabaei, M., et al. (2017). Optimization of photochemical decomposition acetamiprid pesticide from aqueous solutions and effluent toxicity assessment by Pseudomonas aeruginosa BCRC using response surface methodology. $A M B$ Express 7, 1-12. doi: 10.1186/s13568-017-0455-5

Ugwuodo, C. J., and Nwagu, T. N. (2020). Stabilizing enzymes by immobilization on bacterial spores: a review of literature. Int. J. Biol. Macromol. 166, 238-250. doi: 10.1016/j.ijbiomac.2020.10.171

Wang, C.-F., Zhang, Z., and Sun, W. (2018). Ecdysone oxidase and 3-

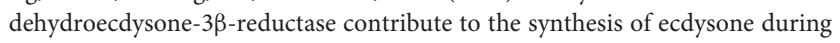
early embryonic development of the silkworm. Int. J. Biol. Sci. 14:1472. doi: 10.7150/ijbs.26227

Wang, G., Yue, W., Liu, Y., Li, F., Xiong, M., and Zhang, H. (2013a). Biodegradation of the neonicotinoid insecticide Acetamiprid by bacterium Pigmentiphaga sp. strain AAP-1 isolated from soil. Bioresour. Technol. 138, 359-368. doi: 10.1016/j.biortech.2013.03.193 
Wang, G., Zhao, Y., Gao, H., Yue, W., Xiong, M., Li, F., et al. (2013b). Co-metabolic biodegradation of acetamiprid by Pseudoxanthomonas sp. AAP-7 isolated from a long-term acetamiprid-polluted soil. Bioresour. Technol. 150, 259-265. doi: 10.1016/j.biortech.2013.10.008

Wang, J., Chen, J., Zhu, W., Ma, J., Rong, Y., and Cai, Z. (2016). Isolation of the novel chiral insecticide paichongding (IPP) degrading strains and biodegradation pathways of RR/SS-IPP and SR/RS-IPP in an aqueous system. J. Agric. Food Chem. 64, 7431-7437. doi: 10.1021/acs.jafc.6b02862

Wang, H., Huang, Y., Shen, C., Wu, J., Yan, A., and Zhang, H. (2016). Cotransport of pesticide acetamiprid and silica nanoparticles in biochar-amended sand porous media. J. Environ. Qual. 45, 1749-1759. doi: 10.2134/jeq2016.02. 0073

Wang, X., Xue, L., Chang, S., He, X., Fan, T., Wu, J., et al. (2019c). Bioremediation and metabolism of clothianidin by mixed bacterial consortia enriched from contaminated soils in Chinese greenhouse. Process Biochem. 78, 114-122. doi: 10.1016/j.procbio.2018.12.031

Wang, J., Tanaka, Y., Ohno, H., Jia, J., Mori, T., Xiao, T., et al. (2019b). Biotransformation and detoxification of the neonicotinoid insecticides nitenpyram and dinotefuran by Phanerochaete sordida YK-624. Environ. Pollut. 252, 856-862. doi: 10.1016/j.envpol.2019.06.022

Wang, J., Ohno, H., Ide, Y., Ichinose, H., Mori, T., Kawagishi, H., et al. (2019a). Identification of the cytochrome P450 involved in the degradation of neonicotinoid insecticide acetamiprid in Phanerochaete chrysosporium. J. Hazard. Mater. 371, 494-498. doi: 10.1016/j.jhazmat.2019.03.042

Wang, Y., Wang, H., Wang, X., Xiao, Y., Zhou, Y., Su, X., et al. (2020). Resuscitation, isolation and immobilization of bacterial species for efficient textile wastewater treatment: a critical review and update. Sci. Total Environ. 730:139034. doi: 10.1016/j.scitotenv.2020.139034

Wang, W., Wan, Q., Li, Y., Ge, J., Feng, F., and Yu, X. (2020). Application of an Endophyte Enterobacter sp. TMX13 to Reduce Thiamethoxam Residues and Stress in Chinese Cabbage (Brassica chinensis L). J. Agric. Food Chem. 68, 9180-9187. doi: 10.1021/acs.jafc.0c03523

Wang, X., Qiu, J., Xu, Y., Liao, G., Jia, Q., Pan, Y., et al. (2021). Integrated non-targeted lipidomics and metabolomics analyses for fluctuations of neonicotinoids imidacloprid and acetamiprid on Neuro-2a cells. Environ. Pollut. 284:117327. doi: 10.1016/j.envpol.2021.117327

Wicker, J., Fenner, K., Ellis, L., Wackett, L., and Kramer, S. (2010). Predicting biodegradation products and pathways: a hybrid knowledgeand machine learning-based approach. Bioinformatics 26, 814-821. doi: 10.1093/bioinformatics/btq024

Wood, T. J., and Goulson, D. (2017). The environmental risks of neonicotinoid pesticides: a review of the evidence post 2013. Environ. Sci. Pollut. Res. 24, 17285-17325. doi: 10.1007/s11356-017-9240-x

Woodcock, B., Bullock, J., Shore, R., Heard, M., Pereira, M., Redhead, J., et al. (2017). Country-specific effects of neonicotinoid pesticides on honey bees and wild bees. Science 356, 1393-1395. doi: 10.1126/science.aaa1190

Wu, C., Wang, Z., Ma, Y., Luo, J., Gao, X., Ning, J., et al. (2021). Influence of the neonicotinoid insecticide thiamethoxam on soil bacterial community composition and metabolic function. J. Hazard. Mater. 405:124275. doi: 10. 1016/j.jhazmat.2020.124275

Wu, Y., Xu, H., Pan, Y., Gao, X., Xi, J., Zhang, J., et al. (2018). Expression profile changes of cytochrome P450 genes between thiamethoxam susceptible and resistant strains of Aphis gossypii Glover. Pestic. Biochem. Physiol. 149, 1-7. doi: 10.1016/j.pestbp.2018.05.007

Xu, B., Xue, R., Zhou, J., Wen, X., Shi, Z., Chen, M., et al. (2020). Characterization of acetamiprid biodegradation by the microbial consortium ACE-3 enriched from contaminated soil. Front. Microbiol. 11:1429. doi: 10.3389/fmicb.2020.01429

Yang, H., Hu, S., Wang, X., Chuang, S., Jia, W., and Jiang, J. (2020). Pigmentiphaga sp. strain D-2 uses a novel amidase to initiate the catabolism of the neonicotinoid insecticide acetamiprid. Appl. Environ. Microbiol. 86, e02425-19. doi: 10.1128/aem.02425-19

Yang, H., Wang, X., Zheng, J., Wang, G., Hong, Q., Li, S., et al. (2013). Biodegradation of acetamiprid by Pigmentiphaga sp. D-2 and the degradation pathway. Int. Biodeter. Biodegr. 85, 95-102. doi: 10.1016/j.ibiod.2013.03.038

Yang, W., Fan, Z., Jiang, H., Zhao, Y., Guo, L., and Dai, Y. (2021). Biotransformation of flonicamid and sulfoxaflor by multifunctional bacterium Ensifer meliloti CGMCC 7333. J. Environ. Sci. Heal. B. 56, 122-131. doi: 10. $1080 / 03601234.2020 .1852854$
Yang, W.-L., Dai, Z.-L., Cheng, X., Guo, L., Fan, Z.-X., Ge, F., et al. (2020). Sulfoxaflor degraded by Aminobacter sp. CGMCC 1.17253 through hydration pathway mediated by nitrile hydratase. J. Agricul. Food Chem. 68, 4579-4587. doi: 10.1021/acs.jafc.9b06668

Ye, S., Yan, M., Tan, X., Liang, J., Zeng, G., Wu, H., et al. (2019). Facile assembled biochar-based nanocomposite with improved graphitization for efficient photocatalytic activity driven by visible light. Appl. Catal. B-Environ. 250, 78-88. doi: 10.1016/j.apcatb.2019.03.004

Yu, B., Chen, Z., Lu, X., Huang, Y., Zhou, Y., Zhang, Q., et al. (2020). Effects on soil microbial community after exposure to neonicotinoid insecticides thiamethoxam and dinotefuran. Sci. Total Environ. 725:138328. doi: 10.1016/j. scitotenv.2020.138328

Yu, H., Lee, K., Zhang, X., and Choo, K.-H. (2019). Core-shell structured quorum quenching beads for more sustainable anti-biofouling in membrane bioreactors. Water Res. 150, 321-329. doi: 10.1016/j.watres.2018.11.071

Yue, W., Chen, M., Cheng, Z., Xie, L., and Li, M. (2018). Bioaugmentation of strain Methylobacterium sp. C1 towards p-nitrophenol removal with broad spectrum coaggregating bacteria in sequencing batch biofilm reactors. J. Hazard. Mater. 344, 431-440. doi: 10.1016/j.jhazmat.2017.10.039

Zamule, S. M., Dupre, C. E., Mendola, M. L., Widmer, J., Shebert, J. A., Roote, C. E., et al. (2021). Bioremediation potential of select bacterial species for the neonicotinoid insecticides, thiamethoxam and imidacloprid. Ecotoxicol. Environ. Saf. 209:111814. doi: 10.1016/j.ecoenv.2020.111814

Zdarta, J., Meyer, A. S., Jesionowski, T., and Pinelo, M. (2018). Developments in support materials for immobilization of oxidoreductases: a comprehensive review. Advan. Colloid Inter. Sci. 258, 1-20. doi: 10.3390/catal8020092

Zdarta, J., Meyer, A. S., Jesionowski, T., and Pinelo, M. (2019). Multi-faceted strategy based on enzyme immobilization with reactant adsorption and membrane technology for biocatalytic removal of pollutants: a critical review. Biotech. Advan. 37:107401. doi: 10.1016/j.biotechadv.2019.05.007

Zhan, H., Wan, Q., Wang, Y., Cheng, J., Yu, X., and Ge, J. (2021). An endophytic bacterial strain, Enterobacter cloacae TMX-6, enhances the degradation of thiamethoxam in rice plants. Chemosphere 269, 128751. doi: 10.1016/j. chemosphere.2020.128751

Zhang, H.-J., Zhou, Q.-W., Zhou, G.-C., Cao, Y.-M., Dai, Y.-J., Ji, W.-W., et al. (2012). Biotransformation of the neonicotinoid insecticide thiacloprid by the bacterium Variovorax boronicumulans strain $\mathrm{J1}$ and mediation of the major metabolic pathway by nitrile hydratase. J. Agric. Food Chem. 60, 153-159. doi: $10.1021 /$ jf203232u

Zhang, P., Sun, H., Min, L., and Ren, C. (2018b). Biochars change the sorption and degradation of thiacloprid in soil: insights into chemical and biological mechanisms. Environ. Pollut. 236, 158-167. doi: 10.1016/j.envpol.2018. 01.030

Zhang, P., Ren, C., Sun, H., and Min, L. (2018a). Sorption, desorption and degradation of neonicotinoids in four agricultural soils and their effects on soil microorganisms. Sci. Total Environ. 615, 59-69. doi: 10.1016/j.scitotenv.2017. 09.097

Zhao, G. P., Yang, F. W., Li, J. W., Xing, H. Z., Ren, F. Z., Pang, G. F., et al. (2020). Toxicities of neonicotinoid-containing pesticide mixtures on nontarget organisms. Environ. Toxicol. Chem. 39, 1884-1893. doi: 10.1002/etc.4842

Zhao, Y.-J., Dai, Y.-J., Yu, C.-G., Luo, J., Xu, W.-P., Ni, J.-P., et al. (2009). Hydroxylation of thiacloprid by bacterium Stenotrophomonas maltophilia CGMCC1. 1788. Biodegradation 20, 761. doi: 10.1007/s10532-009-9264-0

Zhao, Y.-X., Jiang, H.-Y., Cheng, X., Zhu, Y.-X., Fan, Z.-X., Dai, Z.-L., et al. (2019b). Neonicotinoid thiacloprid transformation by the N2-fixing bacterium Microvirga flocculans CGMCC 1.16731 and toxicity of the amide metabolite. Int. Biodeter. Biodeger. 145:104806. doi: 10.1016/j.ibiod.2019.104806

Zhao, Y.-X., Guo, L.-L., Sun, S.-L., Guo, J.-J., and Dai, Y.-J. (2019a). Bioconversion of indole-3-acetonitrile by the N 2-fixing bacterium Ensifer meliloti CGMCC 7333 and its Escherichia coli-expressed nitrile hydratase. Int. Microbiol. 23, 225-232. doi: 10.1007/s10123-019-00094-0

Zhou, G. C., Wang, Y., Ma, Y., Zhai, S., Zhou, L. Y., Dai, Y. J., et al. (2014). The metabolism of neonicotinoid insecticide thiamethoxam by soil enrichment cultures, and the bacterial diversity and plant growth-promoting properties of the cultured isolates. J. Environ. Sci. Heal. B 49, 381-390. doi: 10.1080/ 03601234.2014 .894761

Zhou, G.-C., Wang, Y., Zhai, S., Ge, F., Liu, Z.-H., Dai, Y.-J., et al. (2013). Biodegradation of the neonicotinoid insecticide thiamethoxam by the 
nitrogen-fixing and plant-growth-promoting rhizobacterium Ensifer adhaerens strain TMX-23. Appl. Microbiol. Biotechnol. 97, 4065-4074. doi: 10.1007/ s00253-012-4638-3

Zhou, L.-Y., Zhang, L.-J., Sun, S.-L., Ge, F., Mao, S.-Y., Ma, Y., et al. (2014). Degradation of the neonicotinoid insecticide acetamiprid via the N-carbamoylimine derivate (IM-1-2) mediated by the nitrile hydratase of the nitrogen-fixing bacterium Ensifer meliloti CGMCC 7333. J. Agric. Food Chem. 62, 9957-9964. doi: 10.1021/jf503557t

Conflict of Interest: The authors declare that the research was conducted in the absence of any commercial or financial relationships that could be construed as a potential conflict of interest.
Publisher's Note: All claims expressed in this article are solely those of the authors and do not necessarily represent those of their affiliated organizations, or those of the publisher, the editors and the reviewers. Any product that may be evaluated in this article, or claim that may be made by its manufacturer, is not guaranteed or endorsed by the publisher.

Copyright () 2021 Ahmad, Cui, Zhong and Liu. This is an open-access article distributed under the terms of the Creative Commons Attribution License (CC BY). The use, distribution or reproduction in other forums is permitted, provided the original author(s) and the copyright owner(s) are credited and that the original publication in this journal is cited, in accordance with accepted academic practice. No use, distribution or reproduction is permitted which does not comply with these terms. 